Boston University School of Law Scholarly Commons at Boston University School of Law

Faculty Scholarship

1982

Fair Use as Market Failure: A Structural and Economic Analysis of the Betamax Case and its Predecessors

Wendy J. Gordon

Follow this and additional works at: https://scholarship.law.bu.edu/faculty_scholarship

Part of the Intellectual Property Law Commons 


\title{
Fair Use as Market Failure: A Structural and Economic Analysis of the Betamax Case and its Predecessors
}

\author{
Wendy J. Gordon*
}

In the recent and much publicized Universal City Studios, Inc. v. Sony Corp. of America (Betamax) case, ${ }^{1}$ the Court of Appeals for the Ninth Circuit held that persons who make videotapes of copyrighted television programs in the privacy of their homes should be considered to be copyright infringers. ${ }^{2}$ Basic to the court's reasoning was a misunderstanding of the "fair use" doctrine. Called "the most troublesome [doctrine] in the whole law of copyright," "fair use" renders noninfringing certain uses of copyrighted material that might technically violate the statute, but which do not violate the statute's basic purposes.

The Ninth Circuit took the position that "fair use" could only protect users who were productive second authors, and not persons who were making ordinary or "intrinsic" use like the home videotapers. ${ }^{4}$ In doing so, the circuit court rejected explicitly the economically oriented approach to fair use adopted by the Court of Claims in Williams \& Wilkins Co. $v$. United States. ${ }^{5}$

In its opinion in Williams \& Wilkins, which was affirmed by an equally divided Supreme Court in $1975,{ }^{6}$ the Court of Claims held that massive photocopying efforts by libraries could in some circumstances constitute fair use. $^{7}$ The Supreme Court has recently granted certiorari in the Betamax case, ${ }^{8}$

\footnotetext{
*Associate Professor of Law, Western New England College School of Law (on leave of absence with Weil, Gotshal, \& Manges for the academic year 1982-83). A.B. 1971, Cornell University; J.D. 1975, University of Pennsylvania Law School. The views expressed herein are solely those of the author.

I would like to thank Professors Bruce A. Ackerman of the Columbia University School of Law, Robert A. Gorman of the University of Pennsylvania Law School, and Warren F. Schwartz of the Georgetown University Law Center for their helpful comments on earlier versions of this Article. Responsibility for all errors, of course, rests with me. The Article was prepared with the aid of a research grant from Western New England College School of Law. Students Anne Cohen, Patrick Lang and Charles Stephenson provided valuable research assistance.

The Article is dedicated to Norman W. Bernstein.

1. 659 F.2d 963 (9th Cir. 1981), cert. granted, 102 S. Ct. 2926 (1982) (No. 81-1687).

2. Id. at 969 .

3. Dellar v. Samuel Goldwyn, Inc., 104 F.2d 661, 662 (2d Cir. 1939) (per curiam). The complexity of the issues underlying fair use has been recognized since its inception. See, c.g., Folsom v. Marsh, 9 F. Cas. 342, 344-45 (C.C.D. Mass. 1841) (No. 4901).

4. Universal City Studios, 659 F.2d at 970 ; see also id. at 971 (new technology strains the fair use doctrine in removing control of access from the author). The court relied there on a thoughtful work by Leon Seltzer. Seltzer, Exemptions and Fair Use in Copyright: The "Exclusive Rights" Tensions in the New Copyright Act, 24 Bull. Copyright Soc'y 215 (1977), reprinted in L. Seltzer, Exemptions and Fair Use In Copyright (1978).

5. 487 F.2d 1345 (Ct. Cl. 1973), aff'd by an equally divided court, 420 U.S. 376 (1975) (per curiam).

6. 420 U.S. 376 (1975) (per curiam).

7. The Williams \& Wilkins opinion is discussed infra notes 249-88 and accompanying text. 1687.

8. Sony Corp. of America v. Universal City Studios, Inc., 102 S. Ct. 2926 (1982) (No. 81-
} 
and may take this occasion to choose between the Court of Claims's approach and the more restrictive doctrinal views of the Ninth Circuit.

This Article suggests that the Court of Claims opinion in Williams \& Wilkins, while flawed in many of its aspects, ${ }^{9}$ did not err in seeking a base for fair use in structural and economic considerations. Specifically, it will be argued that the fair use doctrine, though sometimes called an "equitable rule of reason" for which no definition is possible, ${ }^{10}$ has at bottom three straightforward concerns. Where (1) defendant could not appropriately purchase the desired use through the market; ${ }^{11}$ (2) transferring control over the use to defendant would serve the public interest; ${ }^{12}$ and (3) the copyright owner's incentives would not be substantially impaired by allowing the user to proceed, ${ }^{13}$ courts have in the past considered, and should in the future consider, defendant's use "fair." While other approaches to fair use may legitimately be advanced, much of fair use depends on the resolution of these concerns.

This Article will suggest that, contrary to the Ninth Circuit's view, the "productive" status of a user is at best merely a secondary indicator that these concerns may be satisfied. ${ }^{14}$ On a more fundamental level, the Article will illustrate how the courts and Congress have employed fair use to permit uncompensated transfers that are socially desirable but not capable of effectuation through the market. ${ }^{15}$ The market approach will provide a guide both to ascertaining where the public interest might lie in a given case, and to identifying those occasions on which a court may appropriately substitute its evaluation of the public interest for its usual refusal to second-guess the copyright owner. Through analysis of the Williams \& Wilkins ${ }^{16}$ and Betamax ${ }^{17}$ cases, the Article will also indicate how a market approach can serve as a means for applying fair use to newly emerging uses of copyrighted works made possible

9. This Article will analyze critically certain aspects of the Court of Claims's opinion, see infra notes 260-88 and accompanying text. Other aspects of the opinion have been the subject of much analysis. See, e.g., Nimmer, Photocopying and Record Piracy: Of Dred Scott and Alice in Wonderland, 22 U.C.L.A. L. Rev. 1052 (1975).

10. "[S]ince the doctrine is an equitable rule of reason, no generally applicable definition is possible, and each case raising the question must be decided on its own facts." H.R. Rep. No. 1476, 94th Cong., 2d Sess. 65 (1976) [hereinafter cited as House Report], reprinted in 1976 U.S. Code Cong. \& Ad. News 5659, 5679.

In 1961, the then Register of Copyrights described fair use as follows: “ '[F]air use' . . . eludes precise definition; broadly speaking, it means that a reasonable portion of a copyrighted work may be reproduced without permission when necessary for a legitimate purpose which is not competitive with the copyright owner's market for his work." Staff of House Comm. on the Judiciary, 87th Cong., 1st Sess., Copyright Law Revision, Report of the Register of Copyrights on the General Revision of the U.S. Copyright Law 24 (Comm. Print 1961). Another often quoted definition is that fair use is a "privilege in others than the owner of a copyright to use the copyrighted material in a reasonable manner without his consent, notwithstanding the monopoly granted to the owner." H. Ball, The Law of Copyright and Literary Property 260 (1944).

11. See infra text accompanying notes $89-91$ \& $150-98$.

12. See infra text accompanying notes 92-103 \& 199-240.

13. See infra text accompanying notes 104-24 \& 241-47.

14. See infra text accompanying notes 295-307.

15. See infra notes $150-240 \& 295-97$ and accompanying text.

16. See infra text accompanying notes $249-88$.

17. See infra text accompanying notes 289-322. 
by developing technologies. Overall, by unifying the various traditional fair use factors into one economic model, the Article aims to serve as an aid to predicting fair use results and as a guide to future development of the doctrine.

\section{COPYRIGHTS AND MARKETS}

\section{A. Origins of the American Copyright System and the Doctrine of Fair Use}

The Constitution gives Congress power to grant to authors and inventors exclusive rights over their works in order to "promote the Progress of Science and useful Arts." 18 Beginning in 1790, Congress passed a series of copyright statutes; ${ }^{19}$ the general goal of these statutes has been to establish an incentive for authors to create, by providing them an avenue for obtaining remuneration..$^{20}$ The ultimate goal is not author remuneration, however, but the advancement and dissemination of culture and knowledge. ${ }^{21}$

In most cases, the incentive and dissemination purposes of copyright will not conflict. Authors will be encouraged to produce and distribute new works because the copyright laws give authors the means of being paid for their efforts. Madison foresaw exactly this result when he advocated a congressional copyright and patent power in The Federalist Papers: "The public good," he wrote, "fully coincides . . . with the claims of individuals." 22 Nevertheless, tensions are possible, and over time various copyright doctrines have evolved to guard against the possibility that the author's right of control over his works could defeat rather than serve the public interest in dissemination. "Fair use" is recognized as one such doctrine; it seeks to accommodate the author's need for remuneration and control while recognizing that in specific instances the author's rights must give way before a social need for access and use. ${ }^{23}$ In other words, the fair use doctrine allows an individual, in certain circumstances, to make use of at least a part of an author's work without obtaining that author's consent or recompensing the author for that use.

Historically, it has been no simple matter to decide the appropriate boundaries of an author's control. ${ }^{24}$ As noted above, the fair use doctrine in

18. U.S. Const. art. I, § 8, cl. 8 .

19. For an overview of copyright history, see B. Kaplan, An Unhurried View of Copyright 1-38 (1967); A. Latman \& R. Gorman, Copyright for the Eighties 1-10 (1981).

20. See, e.g., Mazer v. Stein, 347 U.S. 201, 219 (1954).

21. See, e.g., Rosemont Enter., Inc. v. Random House, Inc., 366 F.2d 303, 307 (2d Cir. 1966), cert. denied, 385 U.S. 1009 (1967). The current debates on fair use do not attack this general principle, but center on the extent to which the incentive purpose requires enforcement of the author's right "to control the cost of and access to" his production in varying circumstances. Universal City Studios v. Sony Corp. of America, 659 F.2d 963, 965 (9th Cir. 1981), cert. granted, 102 S. Ct. 2926 (1982) (No. 81-1687).

22. The Federalist No. 43, at 272 (J. Madison) (C. Rossiter ed. 1961).

23. See, e.g., Rosemont Enter., Inc. v. Random House, Inc., 366 F.2d 303, 306-07 (2d Cir. 1966), cert. denied, 385 U.S. 1009 (1967); Triangle Publications, Inc. v. Knight-Ridder Newspapers, Inc., 626 F.2d 1171, 1173-75 (5th Cir. 1980).

24. See generally B. Kaplan, supra note 19. 
particular has been called "the most troublesome in the whole law of copyright," 25 and has traced a quicksilver course of judicial development. Congress, in codifying the fair use exception in the Copyright Act of 1976, refused to formulate a specific test for determining when a particular use is fair use. Instead Congress gave statutory recognition to a list of factors that courts have looked to in making their fair use determinations. ${ }^{26}$ Four factors are enumerated in the statute:

(1) the purpose and character of the use, including whether such use is of a commercial nature or is for non-profit educational purposes; (2) the nature of the copyrighted work; (3) the amount and substantiality of the portion used in relation to the copyrighted work as a whole; and (4) the effect of the use upon the potential market for and value of the copyrighted work..$^{27}$

Congress recognized that even for the courts that had developed the criteria, the factors were "in no case definitive or determinative" but rather "provided some guage [sic] for balancing the equities;" 28 the statutory list is nonexhaustive. ${ }^{2 \theta}$ In addition, Congress encouraged further evolution of the fair use doctrine in the courts. ${ }^{30}$

25. Universal City Studios v. Sony Corp. of America, 659 F.2d 963, 969 (9th Cir. 1981) (quoting Dellar v. Samuel Goldwyn, Inc., 104 F.2d 661 (2d Cir. 1939)), cert. granted, 102 S. Ct. 2926 (1982) (No. 81-1687).

26. The doctrine of fair use was first accorded statutory recognition in the 1976 revision of the Copyright Act. The statute provides:

$\S 107$. Limitations on exclusive rights: Fair use

Notwithstanding the provisions of section 106, the fair use of a copyrighted work, including such use by reproduction in copies or phonorecords or by any other means specified by that section, for purposes such as criticism, comment, news reporting, teaching (including multiple copies for classroom use), scholarship, or research, is not an infringement of copyright. In determining whether the use made of a work in any particular case is a fair use the factors to be considered shall include-

(1) the purpose and character of the use, including whether such use is of a commercial nature or is for nonprofit educational purposes;

(2) the nature of the copyrighted work;

(3) the amount and substantiality of the portion used in relation to the copyrighted work as a whole; and work.

(4) the effect of the use upon the potential market for or value of the copyrighted

17 U.S.C. § 107 (1976).

The legislative history of $\S 107$ of the 1976 Copyright Act indicates that, despite the statutory recognition accorded fair use, the nature of the doctrine remains to be defined by case law: "The bill endorses the purpose and general scope of the judicial doctrine of fair use, but there is no disposition to freeze the doctrine in the statute ... "House Report, supra note 10, at 66, reprinted in 1976 U.S. Code Cong. \& Ad. News at 5680. See also S. Rep. No. 473, 94th Cong., 1st Sess. 62 (1975) [hereinafter cited as Senate Report]. The courts have recognized their freedom to continue the development of fair use doctrine. See, e.g., Triangle Publications, Inc. v. KnightRidder Newspapers, Inc., 626 F.2d 1171, 1174 (5th Cir. 1980) ("Congress made clear that it in no way intended to depart from Court-created principles or to short-circuit further judicial development .....").

27. 17 U.S.C. § 107 (1976).

28. House Report, supra note 10, at 65, reprinted in 1976 U.S. Code Cong. \& Ad. News at 5679.

29. The 1976 Copyright Act provides that "[i]n determining whether the use . . . is a fair use the factors to be considered shall include" those factors listed in the text. 17 U.S.C. § 107 (1976). The Act provides that the term "including" is "illustrative and not limitative." Id. § 101. See also 
It is not clear how much weight should be given to any one of the four factors, what additional factors should be considered, or whether any one of the factors is a sine qua non for a finding of fair use. ${ }^{31}$ Though the factors do implicitly direct courts to identify both the social need for the use and the possible impact on the author's economic expectations, the ambiguity of the fair use doctrine and its statutory formulation obscure the underlying issues and make consistency and predictability difficult to achieve. Some underlying principles, more specific and thus more informative than the identification of basic incentive/dissemination tensions, must be divined beneath the factors to permit their coherent application.

An economic analysis of the copyright system will serve to illuminate these underlying principles. Since the copyright system creates private property in creative works so that the market can simultaneously provide economic incentives for authors and disseminate authored works, it may be useful to begin-if not to end-the fair use inquiry by using economic principles of market failure to identify the situations in which these two goals are likely to conflict. The same economic considerations that guide the copyright system as a whole can also be used to suggest modes of resolving the conflicts, providing a method of applying fair use both to achieve desirable dissemination and to avoid the erosion of incentives. This economic view of fair use can provide a

House Report, supra note 10, at 66, reprinted in 1976 U.S. Code Cong. \& Ad. News at 5681-83 ("Beyond a very broad statutory explanation of what fair use is and some of the criteria applicable to it, the courts must be free to adapt the doctrine to particular situations on a case-bycase basis."). The Fifth Circuit recognized the open-ended nature of the statute, but also indicated that "normally these four factors would govern the analysis." Triangle Publications, Inc. v. Knight-Ridder Newspapers, Inc., 626 F.2d 1171, 1175 n.10 (5th Cir. 1980).

30. See supra note 26 .

31. The courts have reached varying results on these questions. The Fifth Circuit, for example, recognized that " $[t]$ he statute does not indicate how much weight is to be accorded each factor" but considered "the fourth factor, the effect of the use upon the potential market for or the value of the copyrighted work" to be the most important. Triangle Publications, Inc. v. Knight-Ridder Newspapers, Inc., 626 F.2d 1171, 1175 (5th Cir. 1980). Other courts have placed much emphasis on the amount and substantiality of the portion copied (the third factor). The Triangle opinion stated that "the idea that the copying of an entire copyrighted work can never be fair use 'is an overbroad generalization, unsupported by the decisions and rejected by years of accepted practice.' "Id. at 1177 n.15 (quoting Williams \& Wilkins Co. v. United States, 487 F.2d 1345, 1353, 203 Ct. Cl. 74 (1973), aff'd by an equally divided court, 420 U.S. 376 (1975) (per curiam) (citing cases)) (reproduction of copyrighted magazine covers in competitor's comparative advertisements held to be fair use). The district court in the Betamax case took a similar position, in its functional approach to substantiality. See Universal City Studios, Inc. v. Sony Corp. of America, 480 F. Supp. 429, 454-56 (C.D. Cal. 1979), rev'd in part and remanded 659 F.2d 963 (9th Cir. 1981), cert. granted, 102 S. Ct. 2926 (1982) (No. 81-1687). See also the "Agreement on Guidelines for Classroom Copying in Not-For-Profit Educational Institutions." House Report, supra note 10, at 68-70, reprinted in 1976 U.S. Code Cong. \& Ad. News at 5681-83 (copying of "complete poem," "complete article, story, or essay" will be fair use if other conditions are met). By contrast, the Ninth Circuit intimated that it weighed the quantity of copying quite heavily, regardless of its functional impact. Universal City Studios, Inc. v. Sony Corp. of America, 659 F.2d 963, 973 (9th Cir. 1981), cert. granted, 102 S. Ct. 2926 (1982) (No. 81-1687).

Congress took the position that, "[T]he endless variety of situations and combinations of circumstances that can rise [sic] in particular cases precludes the formulation of exact rules in the statute." House Report, supra note 10, at 65-66, reprinted in 1976 U.S. Code Cong. \& Ad. News at $5675-80$. 
coherent approach to application of the traditional factors and their emerging companions.

\section{B. An Overview of the Market Model}

Markets are systems for consensual exchange of owned goods. Private ownership is, of course, only one of many ways in which persons can be encouraged to make productive use of resources, ${ }^{32}$ and our legal, economic and social systems respond with other modes of resource control when the markets fail to generate economically desirable outcomes ${ }^{33}$ or when using the market process would threaten other social goals. ${ }^{34}$ This Article will show that fair use should be interpreted as a mode of judicial response to market failure in the copyright context, and that the presence or absence of the indicia of market failure provides a previously missing rationale for predicting the outcome of fair use cases.

1. The Market System. Economists in the tradition of Adam Smith defend our society's primary dependence on markets by arguing that individual transactions in the marketplace serve both social needs and the needs of the individual persons participating. ${ }^{35}$ Among other contentions, they suggest that the monetary value a person places on a resource will reflect the value that the person's use of the resource will bring to society, so that voluntary transfers between individuals will create a socially desirable pattern of resource allocation. ${ }^{36}$

32. Thomas C. Schelling has written:

A good part of social organization-of what we call society-consists of institutional arrangements to overcome ... divergences between perceived individual interest and some larger collective bargain. Some of it is market-oriented-ownership, contracts, damage suits, patents and copyrights, promissory notes, rental agreements, and a variety of communications and information systems. Some have to do with government-taxes to cover public services, protection of persons, a weather bureau if weather information is not otherwise marketable, one-way streets, laws against littering, wrecking crews to clear away that car in the southbound lane and policemen to wave us on in the northbound lane. More selective groupings-the union, the club, the neighborhoodcan organize incentive systems or regulations to try to help people do what individually they wouldn't but collectively they may wish to do. Our morals can substitute for markets and regulations, in getting us sometimes to do from conscience the things that in the long run we might elect to do only if assured of reciprocation.

T. Schelling, Micromotives and Macrobehavior 127-28 (1978).

33. See generally R. Posner, Economic Analysis of Law 11-12 (2d ed. 1977). Market failure, its effect on economic efficiency, and the variety of available cures are recurrent themes in Judge Posner's text. Some significant forms of allocative inefficiency are reviewed in Markovitz, The Causes and Policy Significance of Pareto Resource Misallocation: A Checklist for Micro-Economic Policy Analysis, 28 Stan. L. Rev. 1 (1975).

34. See, e.g., G. Calabresi \& P. Bobbitt, Tragic Choices 31-34 (1978).

35. See generally R. Heilbroner, The Worldly Philosophers 49-72 (5th ed. 1980); A. Smith, Wealth of Nations (E. Canaan ed. 1937). Some argue that a market economy also helps to protect and nurture political freedoms. See, e.g., M. Friedman, Capitalism and Freedom 7-36 (1962).

36. In the examples that follow, "value" will be explored predominantly in terms of how a resource user can serve consumer desires. It should not be forgotten, however, that serving one's own needs also has value in the economic sense. A person's willingness to pay to use an item for personal consumption reflects "social benefit" since each person is a member of society. Also, "value," as defined in connection with willingness to pay, see infra text accompanying note 38 , is 
To understand this approach, consider the example of movie producers who wish to purchase the motion picture rights to a best-selling novel. Smithian economists would posit that each producer's ability to raise funds from investors depends on the amount of revenue that his or her moviemaking is expected to generate. Among producers of varying levels of skill, the producer best able to use the book to satisfy consumer tastes will be in a position to raise the most funds and thus to offer the highest bid. Similarly, the author or other owner of copyright in the novel will sell the rights only if the revenues he could anticipate by exploiting the work himself would be less than the purchaser's bid. Control over the resource will therefore gravitate through consensual transfers to the person in whose hands the resource can best be used to satisfy consumer desires. ${ }^{37}$ In this way value, defined as "human satisfaction as measured by aggregate consumer willingness to pay for goods and services," 38 will be maximized.

of course dependent, inter alia, on distribution of income, and is at best only an indirect measure of desire and benefit. While an exploration of the limitations and virtues of the "value" criterion is beyond the scope of this Article, it should be noted that courts sometimes use intuitive noneconomic measures of social benefit. See infra note 95 and accompanying text.

37. Judge Posner explains this process by using the following example:

Let Farmer A own a piece of land which he anticipates will yield him $\$ 100$ a year, in excess of labor and other costs, indefinitely. Just as the price of a share of common stock expresses the present value of the anticipated earnings to which the shareholder will be entitled, so the present value of a parcel of land that is expected to yield an annual net income of $\$ 100$ can be calculated and is the minimum price that $\mathrm{A}$ will accept in exchange for his property right. Suppose Farmer B believes that he can use A's land more productively than $A$, i.e., that he could net more than $\$ 100$ a year from working A's land. The present value of B's higher expected earnings stream will, of course, exceed the present value calculated by A. Suppose the present value calculated by $A$ is $\$ 1000$ and by B $\$ 1500$. At a price of $\$ 1250$, for example, A will receive $\$ 250$ more than the land is worth to him and B will pay $\$ 250$ less than the land is worth to him. Thus, there are strong incentives for the parties voluntarily to exchange A's land for B's money, and if $\mathrm{B}$ is as he believes a better farmer than $\mathrm{A}$, the transfer will result in an increase in the productivity of the land. Through a succession of such transfers, resources are shifted to their most valuable uses and efficiency in the use of economic resources is thereby maximized.

R. Posner, supra note 33, at 29 (footnotes omitted).

38. Id. at 10 (emphasis omitted). Judge Posner defines "efficiency" as the maximization of "value" so measured. Id. Note that under this definition, it is "efficient" to take resources from a person in whose hands they have less "value" and give them to another person in whose hands they have more "value," even if the loser is not compensated for the transfer. Even aside from the general questions that can be raised concerning any quasi-utilitarian measure, the adequacy of Judge Posner's "value" as a test of public welfare has been often questioned. See, e.g., Leff, Economic Analysis of Law: Some Realism About Nominalism, 60 Va. L. Rev. 451, 477-82 (1974); Polinsky, Economic Analysis As a Potentially Defective Product: A Buyer's Guide to Posner's Economic Analysis of Law, 87 Harv. L. Rev. 1655, 1665, 1679-81 (1974). This Article does not argue that maximizing value is a sufficient justification for all instances of fair use; it argues that the copyright owner must be compensated if denying him control over a contested use of his work would cause him substantial injury. See infra text accompanying notes 104-24. See also generally Michelman, Property, Utility, and Fairness: Comments on the Ethical Foundations of "Just Compensation"' Law, 80 Harv. L. Rev. 1165 (1967) (evaluating "efficiency" and other criteria in the identification of which of the losses occasioned by governmental activity should be noncompensable and which should be entitled to "just compensation").

The traditional criterion that welfare economics has used for "judging whether resource use is efficient" is the Pareto Condition in which "no reallocation can yield improvement for some 
Economists agree that several "conditions of perfect competition" must be satisfied if individual market transactions are to result in the maximization of value. When these conditions are absent, reliance on consensual bargains to achieve socially desirable results may be inappropriate. ${ }^{39}$ One such condition is that all costs and benefits must be "internal" to the transactions that generate them, in the sense that the costs or benefits must be borne by persons with decision-making power in a given transaction and not by persons external to it. ${ }^{40}$ For example, if a resource user is in a field where much of the social benefit produced by his activities does not translate into compensation to him, then he may generate "external benefits" not reflected in his income. In such a case, his willingness to pay for the resource might understate his ability to use it in a way that serves social needs. ${ }^{A 1}$

Perfect competition also requires perfect knowledge; ${ }^{42}$ for example, consumers must know the qualities and characteristics of all available products, ${ }^{43}$ as well as the prices and locations of the various sellers. Consider the impact of imperfect knowledge on the movie producer example advanced earlier. If reviewers give consumers inadequate information about the characteristics of movies produced, the money spent on theater tickets may not reflect the choices that would in fact best satisfy consumer tastes. ${ }^{44}$ As a result, a skillful producer might be unable to raise capital in a way that would accurately

without injury to others." D. Orr, Property, Markets and Government Intervention 100 (1976). See infra note 54. See also J. Hadar, Elementary Theory of Microeconomic Behavior 319-45 (2d ed. 1974); N. Singer, Public Microeconomics: An Introduction to Government Finance 81-85 (2d ed. 1976). However, the Pareto Condition, when interpreted strictly, has only limited usefulness as a criterion because "virtually all policies will harm someone." Markovitz, supra note 33 , at 2 n.2. Thus, a Posnerian use of an aggregate measure to define efficiency is common among legal scholars. See id. at 2 . ("[O]nly rarely does a policy actually move the economy to a Paretopreferred position. Accordingly, I find it more useful to focus on whether a policy seems likely to give its beneficiaries the equivalent of more dollars than it seems likely to take away from its victims.") (footnotes omitted). See also Calabresi \& Melamed, Property Rules, Liability Rules, and Inalienability: One View of the Cathedral, 85 Harv. L. Rev. 1089, 1094 (1972) ("[E]conomic efficiency ... a asks for that form of property, private or communal, which leads to the highest product for the effort of producing.").

39. There may also be occasions in which it is normatively inappropriate to use even a perfectly functioning market. Similarly, enforcement of an author's market right is arguably inappropriate when such enforcement would threaten nonmonetizable first amendment interests. See infra text accompanying notes 170-73. Some commentators have suggested a separate first amendment exception to copyright, while others have suggested recognition of a first amendment dimension to fair use. For valuable introductions to this literature, see Denicola, Copyright and Free Speech: Constitutional Limitations on the Protection of Expression, 67 Calif. L. Rev. 283 (1979); Goldstein, Copyright and the First Amendment, 70 Colum. L. Rev. 983 (1970).

40. See D. Orr, supra note 38, at ch. 15 ("Externalities and Public Goods"); Markovitz, supra note 33 , at 2 . In the absence of transaction costs, this condition will automatically be met, because persons affected by transactions can "bribe" participants within the transactions to take actions in accordance with their interest. See generally Coase, The Problem of Social Cost, 3 J.L. \& Econ. 293 (1970). See R. Posner, supra note 33. See also Markovitz, supra note 33, at 7 n.14.

41. See infra text accompanying notes $170-76,182$.

42. See Markovitz, supra note 33, at 2, 3, 7; Polinsky, supra note 38, at 1667 . See also J. Hadar, supra note 38 , at $\$ 13.4$ ("Behavior Under Uncertainty").

43. See Polinsky, supra note 38 , at 1667.

44. See infra text accompanying note 183 , which suggests that reviews and criticisms may be appropriate subjects for fair use treatment in order to protect the availability of such information. 
reflect his ability to use resources in satisfaction of consumer tastes, ${ }^{45}$ so that his ability to pay for the rights to a novel would understate his ability to use the novel to serve public needs. In a perfect market, his failure to outbid another producer would have been a reliable indicator that the movie rights would be most valuable in the other producer's hands. In a market where information is incomplete or unreliable, however, a failure to outbid the other producer may have no such significance.

Finally, then, perfect competition depends on the absence of transaction costs. ${ }^{46}$ If all desirable transfers are to occur, it must be costless to obtain knowledge ${ }^{47}$ costless to locate all persons affected by a transaction, costless to dicker with them over prices and terms, and costless to maintain an enforcement mechanism to ensure that the bargain is adhered to. ${ }^{48}$ This condition of perfect competition, like the others, is never fully present; some transaction costs are inevitable. ${ }^{49}$ When the transaction costs outweigh the net benefits that the parties would otherwise anticipate from a transfer, then the presence of the transaction costs may block an otherwise desirable shift in resource use. ${ }^{50}$

The legal system acts in diverse ways to increase the probability that these and other conditions for perfect competition will be present. For example, to prevent consumer ignorance, truth-in-lending and labeling disclosure laws may be enacted, ${ }^{51}$ and restrictions on truthful advertising may be struck down. ${ }^{52}$ Similarly, antitrust laws prevent any one buyer or seller from gaining monopoly control that would distort competition..$^{33}$ When the market does not work perfectly, "a decision will often have to be made on whether market transactions or collective fiat is most likely to bring us closer to the . . . result

45. See supra note 37 .

46. Transaction costs are "the costs of effecting a transfer of rights." R. Posner, supra note 33 , at 30 . Where transaction costs are "prohibitive ... exclusivity of property rights may ... reduce rather than increase the efficiency of resource use." Id.

47. The condition of perfect knowledge is thus an aspect of the condition of no transaction costs, but the two are usefully stated separately.

48. If bargains are unenforceable, markets are highly unlikely to form. See R. Posner, supra note 33, at 65-67 (economic rules of contract law). See also Demsetz, The Private Production of Public Goods, 13 J. L. \& Econ. 293, 306 (1970) (when nonpurchasers cannot be excluded from using a public good at a reasonable cost, a system of private production "does not seem to be practical"). This aspect of transaction costs becomes important for the discussion of the Betamax case, infra notes 289-322 and accompanying text.

49. If transaction costs were totally absent, all costs and benefits would necessarily be internalized, and value-maximizing transfers would always take place. See generally Coase, supra note 40; see also Calabresi \& Melamed, supra note 38, at 1094-95 \& n.12. However, transaction costs are inevitable in the real world of economics, and the nature and impact of those transaction costs may be crucial to a determination of legal rights. See id. at 1096.

50. Id. at 1095. Relative as well as absolute levels of transaction costs can be important to market evaluations, as can the issue of who bears those costs. If nonparticipating third parties (e.g., taxpayers) bear the transaction costs, that will insulate the bargaining parties from the impact of those costs.

51. E.g., Truth in Lending Act, 15 U.S.C.A. §§ 1601-1667e (West 1974 \& Supp. 1982); Fair Packaging and Labeling Act, 15 U.S.C. §§ 1451-61 (1976).

52. See Virginia State Bd. of Pharmacy v. Virginia Citizens Consumer Council, Inc., 425 U.S. 748, 770 (1976).

53. See, e.g., R. Posner, supra note 33, at 212-13. 
the 'perfect' market would reach." ${ }^{4}$ One possible response of the law might be the creation of governmental agencies to make resource allocation decisions by regulation. Another might be to set up incentives that encourage the achievement of efficient results even in the absence of markets.

The latter provides the conventional economic explanation for the standard of reasonable care used in negligence law. ${ }^{55}$ In a market transaction, each party is forced to take account of the other's demands through bargaining. In unintentional accidents, a market bargain between the participants is obviously impossible, yet it is desirable for them to take into account the effect of their actions on each other. Negligence law gives a potential defendant the incentive to consider the other person's possible injury. If the costs of the precautions neglected by the defendant are less than the discounted accident costs the precautions would have prevented, ${ }^{56}$ the verdict will be for the plaintiff. ${ }^{57}$ If, on the other hand, the court views the defendant's pre-accident behavior as cost-justified, the plaintiff's injuries will go unrecompensed. ${ }^{58}$

A defendant who deliberately bypasses the market is not likely to find the court willing to act as a resource-allocating mechanism; the market guarantees compensation to the owner, and usually provides a less expensive and more reliable way to determine whether a use is value-maximizing than does the deliberation of a judicial stranger to the transaction. ${ }^{59} \mathrm{~A}$ court generally should engage in balancing costs and benefits only if market failure has left it the only institution able to do so. ${ }^{60}$ This is one reason why, for many intentional torts, the economic desirability of defendant's action is irrelevant to

54. Calabresi \& Melamed, supra note 38, at 1097 (footnote omitted) (referring to the perfect market result as Pareto optimal). The authors define Pareto optimality as "the set of entitlements which would lead to that allocation of resources which could not be improved in the sense that a further change would not so improve the condition of those who gained by it that they could compensate those who lost from it and still be better off than before." Id. at 1094.

55. See, e.g., R. Posner, supra note 33, at 122, 125 . However, both the comparative negligence doctrine and the contributory negligence doctrine inadequately resolve the problem of how to set up incentives when the plaintiff is also negligent. Id. at 123-24. Perhaps the best introduction to the economic analysis of accident law is G. Calabresi, The Costs of Accidents (1970), which ranges far beyond conventional negligence law. See Calabresi's analyses of incentives and market deterrence, id. at 68-94.

56. Costs must be discounted by the probability of their occurrence. See R. Posner, supra note 33 , at $122-23$.

57. See United States v. Carroll Towing Co., 159 F.2d 169, 173 (2d Cir. 1947). See generally R. Posner, supra note 33 , at $119-59$.

58. Whether the prevailing negligence/contributory negligence pattern in fact provides desirable incentives is of course a matter of much debate. See, e.g., R. Posner, supra note 33, at 122-24; note 55 .

59. See Michelman, supra note 38, at 1180 (discussing "the inability of outside observers to appraise ... . efficiency of proposed social measures"). Cf. Hayek, The Use of Knowledge in Society, 35 Am. Econ. Rev. 519, 524-25 (1945) (arguing that decentralized decisionmaking can often utilize knowledge better than can central planning). See also Calabresi \& Melamed, supra note 38 , at 1108, 1115-24 (discussing the "likelihood of error" in assessing costs and benefits under various liability rules); id. at 1125 ("liability rules represent only an approximation of the value of the object to the original owner").

60 . While the focus of this fair use discussion is necessarily on judicial rules of decision, other institutions can also perform the balancing function, and the nature of the institution may affect the appropriate rules or principles to be applied. See Michelman, supra note 38, at 1245-57. 
determining liability; in such cases the defendant could have identified, and thus bargained with, the plaintiff or class of plaintiffs involved. ${ }^{61}$

2. Markets in Copyright. Copyright and patent law create ownership rights in intellectual property, with the primary goal of generating monetary incentives for the production of creative works, thereby "promot[ing] the Progress of Science and useful Arts." ${ }^{22}$ If the creators of intellectual productions were given no rights to control the use made of their works, they might receive few revenues and thus would lack an appropriate level of incentive to create. Fewer resources would be devoted to intellectual productions than their social merit would warrant..$^{63}$

Economists ordinarily characterize intellectual property law as an effort to cure a form of market failure stemming from the presence of "public goods" characteristics. ${ }^{64} \mathrm{~A}$ public good is often described as having two

61. See Calabresi \& Melamed, supra note 38, at 1124-27 (discussing criminal sanctions).

62. U.S. Const. art. I, § 8, cl. 8.

63. The Supreme Court has accepted this premise in several contexts. See, e.g., Mazer v. Stein, 347 U.S. 201, 219 (1954):

The economic philosophy behind the clause empowering Congress to grant patents and copyrights is the conviction that encouragement of individual effort by personal gain is the best way to advance public welfare through the talents of authors and inventors in "Science and useful Arts." Sacrificial days devoted to such creative activities deserve rewards commensurate with the services rendered.

United States v. Paramount Pictures, Inc., 334 U.S. 131, 158 (1948):

The copyright law, like the patent statutes, makes reward to the owner a secondary consideration. In Fox Film Corp. v. Doyal, 286 U.S. 123, 127, Chief Justice Hughes spoke as follows respecting the copyright monopoly granted by Congress, "The sole interest of the United States and the primary object in conferring the monopoly lie in the general benefits derived by the public from the labors of authors." It is said that reward to the author or artist serves to induce release to the public of the products of his creative genius.

The role of copyright law in the maintenance of economic incentives has been a matter of significant debate. See, e.g., Breyer, Copyright: A Rejoinder, 20 U.C.L.A. L. Rev. 75 (1972); Breyer, The Uneasy Case for Copyright: A Study of Copyright in Books, Photocopies, and Computer Programs, 84 Harv. L. Rev. 281, 291-323 (1970) [hereinafter cited as Breyer, The Uneasy Case for Copyright]; Hurt \& Schuchman, The Economic Rationale of Copyright, 56 Am. Econ. Rev. 421 (1966) (1965 Papers \& Proceedings of Am. Econ. Ass'n); Plant, The Economic Aspects of Copyright in Books, 1 Economica 167 (new series 1934); Tyerman, The Economic Rationale for Copyright Protection for Published Books: A Reply to Professor Breyer, 18 U.C.L.A. L. Rev. 1100 (1971). There is also debate about the extent to which the copyright and patent laws serve purposes other than providing incentives. For example, barring potential users from copying encourages them to do their own work. See Gorman, Copyright Protection for the Collection and Representation of Facts, 76 Harv. L. Rev. 1569, 1599 (1963). Intellectual property laws can help structure production to increase the output from resources used for technological innovation. See Kitch, The Nature and Function of the Patent System, 20 J.L. \& Econ. 265 (1977). Copyright may also function to protect the author's own interests in, e.g., the integrity of his work. See Breyer, The Uneasy Case for Copyright, supra, at 284-91; Comment, An Author's Artistic Reputation Under the Copyright Act of 1976, 92 Harv. L. Rev. 1490, 1491 (1979).

Nevertheless, it generally is agreed that American law gives copyright and patent protection to the producers of intangible products primarily because of the legislative judgment that such systems are necessary if producers of intellectual property are to receive a large enough monetary return for their labors and investments to insure continued production. See Zacchini v. ScrippsHoward Broadcasting Co., 433 U.S. 562, 576 (1977).

64. Cf. Liebowitz, Copyright and Photocopying: Alternative Institutional Arrangements 3-5 (Feb. 1981) (unpublished manuscript, on file at Columbia Law Review). How the production of 
defining traits. First, it is virtually inexhaustible once produced, in the sense that supplying additional access to new users would not deplete the supply available to others. Second, and more important for the instant purposes, persons who have not paid for access cannot readily be prevented from using a public good. ${ }^{65}$ Because it is difficult or expensive to prevent "free riders" from using such goods, public goods usually will be under-produced if left to the private market. ${ }^{68} \mathrm{~A}$ familiar example of a public good is national defense. ${ }^{67}$ Since it is not possible to use a radar early-warning network in a way that discriminates between one person who has paid for defense and his neighbor who has not, a less than optimal amount of national defense will be produced if its purchase is left to the usual consensual market mechanisms of voluntary purchase. Some sort of compulsory payment, such as taxation, and central decision-making may be necessary to eliminate free riders and obtain the socially desirable amount of defense. ${ }^{68}$

Books and inventions exhibit certain public goods characteristics. ${ }^{69}$ Once the literary work or the discovery embodied in the invention is made available to the public, the sequence of words or the discovery might be used by countless consumers without exhausting the supply. Any number of persons can simultaneously use the newly invented process or reprint the literature without physically depriving others of its use. Physical control, therefore, does not offer its usual potential as a mode of inexpensive enforcement for excluding free riders. ${ }^{70}$

Though taxation and centralized purchasing might provide a satisfactory solution for some public goods problems, such an approach is inappropriate

public goods should be organized has been the subject of much economic debate. See, e.g., Demsetz, supra note 48 (arguing that under certain circumstances private producers can produce public goods efficiently).

65. See, e.g., E. Mansfield, Principles of Microeconomics 70 (1974); D. Orr, supra note 38, at $285-311$.

"A common, collective, or public good is here defined as any good such that, if any person $\mathrm{Xi}$ in a group $\mathrm{X} 1, \ldots, \mathrm{Xi} . . ., \mathrm{Xn}$ consumes it, it cannot feasibly be withheld from others in the group." M. Olson, The Logic of Collective Action: Public Goods and the Theory of Groups 14 (1971). Although Olson focuses on this characteristic, he notes that another element in the "traditional understanding of public goods" is " 'jointness of supply.' A good has 'jointness' if making it available to one individual means that it can be easily or freely supplied to others as well." Id. at 14 n.21.

Professor Demsetz distinguishes

between the public good concept ... . which states that it is possible at no cost for additional persons to enjoy the same unit of a public good, and a different concept, that might be identified as a collective good, which imposes the stronger condition that it is impossible to exclude nonpurchasers from consuming the good.

Demsetz, supra note 48 , at 295 . Under this view, national defense, which is the example used in text, see text accompanying notes 66-68, "might be termed an 'approximate collective good.' " Demsetz, supra note 48 , at 295.

66. See, e.g., E. Mansfield, supra note 65 , at 70, 74-75. See also Markovitz, supra note 33.

67. See supra note 65 .

68. See, e.g., sources cited supra note 65 .

69. See, e.g., sources cited supra notes 63-65.

70. Cf. Final Report of the National Commission on New Technological Uses of Copyrighted Works [CONTU] 10 (1978) (discussing computer programs):

[I]f the cost of duplicating information is small, then it is simple for a less than scrupulous person to duplicate it. This means that legal as well as physical protection is a 
for much intellectual property. A democratic society demands decentralized and diverse creation in the intellectual sphere; freedom from state control is essential lest freedom of expression be curtailed by fear of governmental reprisal. ${ }^{71}$ Thus, for works of expression, the public goods problem is addressed by another method. Statutes create special property rights for authors; they can sell the physical copies of their works and at the same time retain legal control over the reproduction and certain other uses of the work embodied in those copies. ${ }^{72}$ In other words by the law provides a means for excluding nonpurchasers. ${ }^{73}$ Copyright law therefore allows a market for intellectual property to function.

In addition, the copyright law makes it easy to proceed through consensual market transfer. The requirement that a notice of copyright be placed on all publicly distributed copies facilitates identification of those works that are not in the public domain and cannot be used without purchase of a copyright license, and also facilitates identification of the works' owners. ${ }^{74}$ The registration of copyrights in the Copyright $\mathrm{Office}^{75}$ makes owners relatively easy to locate, and gives further information on the validity and duration of the copyright claimed. To discourage departure from the market system, Congress has made certain copyright violations criminal, ${ }^{76}$ and has established statutory damages and other devices ${ }^{77}$ to lighten a plaintiff's enforcement task. The copyright statute thus facilitates the functioning of the consensual

necessary incentive if such information is to be created and disseminated.

This principle is the underlying principle of copyright ....

See also Liebowitz, supra note 64 , at $4-5$.

Prior to the 1976 Copyright Act, protection of unpublished literary work was left primarily to state law. This so-called "common law" copyright has been argued to have been essentially a right of privacy, see Warren \& Brandeis, The Right To Privacy, 4 Harv. L. Rev. 193, 198-213 (1890), and bears some similarity to state trade secret protection for undisclosed discoveries and inventions. Secret manuscripts are not "public goods"; physical control is sufficient to exclude the unwelcome user.

Common law copyright for expression that is fixed in a tangible medium was abolished by 17 U.S.C. § 301 (1976). See House Report, supra note 10, at 129-33, reprinted in 1976 U.S. Code Cong. \& Ad. News at 5745-49.

71. See Tyerman, supra note 63, at 1117 (exploring the dangers of relying on government subsidies).

72. See 17 U.S.C. § 106 (1976) (exclusive rights in copyrighted works); sources cited supra notes 63-65.

73. Demsetz argues that if nonpurchasers can be excluded efficiency is potentially attainable in a market for public goods. See generally Demsetz, supra note 48.

74. Generally speaking, the notice on copies must show that copyright is claimed by including three elements: "ه" (or "copyright" or "copr."), the year of first publication, and the name of the copyright owner. 17 U.S.C. § 401 (Supp. IV 1980). Under some circumstances omitted or defective notice may be forgiven. Id. §§ 405-06 (Supp. IV 1980). Note that some uses (e.g., private reading and performance) are not within the scope of the copyright owner's exclusive rights.

75. Id. $\$ 408$ (1976). Like the notice requirement, see supra note 74 , the copyright registration requirement is not absolute. See id. Registration is, however, a prerequisite to bringing most infringement actions, id. $\S 411$, and to certain remedies for infringement, id. $\S 412$.

76. Id. § 506.

77. See, e.g., id. § 504(c) (1976) (statutory damages); id. § 501 (prima facie proof of infringement, standing); id. $\S \S 502-505$ (injunctive relief, impoundment, damages, attorneys' fees). Copyright plaintiffs may find it easier to obtain fee awards than defendants. A. Latman \& R. Gorman, supra note 19 , at 538 . 
market ${ }^{78}$ in four ways: it creates property rights, lowers transaction costs, provides valuable information, and contains mechanisms for enforcement.

When the market functions, no finding that the defendant acted "unreasonably" or against the public interest is requisite for judging culpability for the tort of copyright infringement. Like the intentional tortfeasors discussed in the preceding section, ${ }^{79}$ copiers of creative works ordinarily can identify and bargain with copyright owners. If copies are made without permission, the court will not use a "reasonableness" test to second-guess whether the copyist's production was in the public interest. In the ordinary copyright case, the court assumes that the defendant could have, and therefore should have, proceeded through the market..$^{80}$

Copyright markets will not, however, always function adequately. Though the copyright law has provided a means for excluding nonpurchasers and thus has attempted to cure the public goods problem, and though it has provided mechanisms to facilitate consensual transfers, at times bargaining may be exceedingly expensive or it may be impractical to obtain enforcement against nonpurchasers, or other market flaws might preclude achievement of desirable consensual exchanges. ${ }^{81}$ In those cases, the market cannot be relied on to mediate public interests in dissemination and private interests in remuneration. ${ }^{82}$ In extreme instances, Congress may correct for market distortions by imposing a regulatory solution such as a compulsory licensing scheme..$^{83}$ Thus, to avoid threatened monopolistic control over the manufacture of piano rolls and other mechanical recordings, Congress provided that any person who wished could make and sell recordings of copyrighted music, so long as he paid to the copyright owner an amount determined under the statute. ${ }^{84}$ But the broad brush of this regulatory solution is too sweeping for most cases.

78. Note, however, that the copyright law also uses compulsory licensing for some specified classes of works and uses. See, e.g., 17 U.S.C. §111(c)-(d) (1976) (cable television retransmission of copyrighted material); id. $\S 115$ (phonorecords of nondramatic musical works); id. § 116 ('jukebox' performances).

79. See supra text accompanying notes 59-61.

80. See generally Calabresi \& Melamed, supra note 38, at 1125-27 (discussing criminal sanctions for intentional market bypass). Compare the discussion of intentional torts, supra notes 59-61 and accompanying text.

81. As will be seen, the focus is on whether granting fair use to an individual transaction would further the goals of the copyright scheme more than would imposing liability. See generally infra text accompanying notes 92-124. The transactional, case-by-case approach recommended herein does not require identification of any "optimal" level of overall production. Whether excluding nonpurchasers can allow a market in public goods to achieve optimality is itself a matter of debate. Compare Demsetz, supra note 48 (efficiency achievable if nonpurchasers can be excluded from use), with, e.g., Perlman \& Rhinelander, Williams \& Wilkins Co. v. United States: Photocopying, Copyright, and the Judicial Process, 1975 Sup. Ct. Rev. 355, 373-79 (criticizing economic analyses of copyright and fair use). It appears that the copyright law treats the outcome of the ordinary copyright transaction as normatively equivalent to an "optimal" result. This Article seeks to identify what distinguishes an ordinary transactional setting from these settings in which the courts are unwilling to trust markets.

82. Of course, all of the interests are part of society's interests. Compare Michelman, supra note 38, at 1194 (analyzing the nature of balancing tests). At issue also is the public interest is the public interest in preserving incentives.

83. See infra notes 84 \& 131 .

84. Studies prepared for the Subcomm. on Patents, Trademarks and Copyrights of the Senate Comm. on the Judiciary, 86th Cong., 1st Sess., The Compulsory License Provisions of the 
Fair use is one label courts use when they approve a user's departure from the market. A useful starting place for analysis of when fair use is appropriate is therefore an identification of when flaws in the market might make reliance on the judiciary's own analysis of social benefit appropriate. ${ }^{85}$ By making such an identification, a measure of coherence can be brought to the doctrine of fair use. As will be seen, there are certain "conditions of perfect competition"86_or assumptions about how a proper transactional setting should look-whose failure is particularly likely to trigger in the courts an unwillingness to rely on the owner's market right to achieve dissemination. ${ }^{87}$

\section{The Three Part Test for Determining Fair Use}

Fair use should be awarded to the defendant in a copyright infringement action when (1) market failure is present; (2) transfer of the use to defendant is socially desirable; and (3) an award of fair use would not cause substantial injury to the incentives of the plaintiff copyright owner. The first element of this test ensures that market bypass will not be approved without good cause. The second element of the test ensures that the transfer of a license to use from the copyright holder to the unauthorized user effects a net gain in social value. ${ }^{88}$ The third element ensures that the grant of fair use will not undermine the incentive-creating purpose of the copyright law. The test will now be explored in detail.

\section{A. The First Element of the Test: Market Failure}

Because courts in the copyright area ordinarily assume that reliance on the market will serve social purposes, an economic judgment that transfer of a use to defendant will bring a net social benefit should not alone be sufficient

U.S. Copyright Law (Study No. 5) 11 (Comm. Print 1960) (H. Henn). It has been suggested that some of the fears of monopoly may have been unwarranted. See id. at 3 n.20, 11 n.44.

The provisions governing this compulsory license appeared at § 1(e) of the Copyright Act of 1909, 35 Stat. 1075 (codified and reenacted 1947, amended 1976), and appear at $\S 115$ of the 1976 Act. 17 U.S.C. $\S 115$ (1976). The provisions are not triggered until the copyright owner has himself taken some action to avail himself of the possibility of making mechanical recordings.

Compulsory licenses are a likely compromise when new rights are granted. See, e.g., Second Supplementary Report of the Register of Copyrights of the General Revision of U.S. Copyright Law: 1975 Revision Bill (Draft, October-December 1975) at VII 18-20 (fears expressed that extending copyright to typefaces would allow a "few big manufacturers . ... to enforce tying arrangements between their machines and fonts" or "might lead to suits to enjoin publication of printed matter;" "mandatory licensing" discussed as a possible solution). See also 17 U.S.C. § 111 (1976) (cable television retransmission of copyrighted material).

85. This Article does not purport to present an exhaustive list of the reasons why a court might refuse to enforce a copyright owner's market right. It is submitted, however, that in all cases where protected subject matter has been appropriated, the courts should give consideration to whether there is a good reason-founded in economics or otherwise-to depart from the market.

86. See infra notes $149-98$ and accompanying text.

87. This Article will be using economics to identify certain market defects that are particularly salient, and that appear to cause courts to doubt the appropriateness of enforcing a copyright owner's market right.

88. These first two considerations are closely analogous to those at work in the negligence model discussed supra in text accompanying notes 55-58. 
to negate the tort of infringement. If the work is socially more valuable in the buyer's hands, then the economic model has suggested that he will be able to raise sufficient funds to purchase permission from the owner. In other words, to propose that fair use be imposed whenever the "social value . . . outweighs any detriment to the artist," "89 would be to propose depriving copyright owners of their right in the property precisely when they encounter those users who could afford to pay for it. Though a transfer to such user might be socially desirable, there is no need to compel it through fair use. Such transfer will in theory occur voluntarily, through purchase. Further, if the parties could arrive at mutually agreeable terms for a transfer, such an agreement would be a more reliable indicator of the transfer's value-maximizing quality than would a court's distant judgment. ${ }^{90}$

An economic justification for depriving a copyright owner of his market entitlement exists only when the possibility of consensual bargain has broken down in some way. Only where the desired transfer of resource use is unlikely to take place spontaneously, or where special circumstances such as market flaws impair the market's ordinary ability to serve as a measure of how resources should be allocated, is there an economic need for allowing nonconsensual transfer. Thus, one of the necessary preconditions for premising fair use on economic grounds is that market failure must be present. Those types of market failure that are revealed in the fair use cases and statute will be discussed in a later section of this Article. ${ }^{91}$

\section{B. The Second Element of the Test: Balancing Injury and Benefit}

If market failure is present, the court should determine if the use is more valuable in the defendant's hands or in the hands of the copyright owner. ${ }^{92}$ One way of accomplishing that goal is to simulate the market inquiry. If, when the "market failure" were cured, the price that the owner would demand is lower than the price that the user would offer, a transfer to the user will increase social value. ${ }^{93}$

A court may have difficulty in determining what price would have been offered or demanded. For example, as will be shown, fair use is often found where defendant's use of the work is noncommercial and yields "external

89. Note, Parody and Copyright Infringment, 56 Colum. L. Rev. 585, 595 (1956) ("Fair use ... can be defined as a use which will not seriously discourage progress by artists or as a use whose social value greatly outweighs any detriment to the artist whose work is borrowed.") (footnote omitted). See also Marsh, Betamax and Fair Use: A Shotgun Marriage, 21 Santa Clara L. Rev. 49, 58 (1981).

90. See supra note 59 .

91. See infra notes $149-98$ and accompanying text.

92. See supra notes 37-38 and accompanying text. The second part of the test inquires into the minimum price plaintiff would accept in a hypothetical market to recompense him for the injury caused by the defendant's specific use. The broader issue of real-world injury to the market as a whole is the subject of the third part of the test. See infra notes 115-17 and accompanying text. value).

93. See R. Posner, supra note 33 , at 10-12 (voluntary transactions result in a net increase in 
benefits," that is, benefits to society that go uncompensated. ${ }^{04}$ In the presence of such market failure, the price that the defendant user would offer for use of the work will often understate the real social value of his use. The courts in fair use cases frequently make intuitive estimates of social value. ${ }^{95}$

The court's ability to estimate social value may have the assistance of some objective measures. For example, plaintiff's minimum price may depend on the loss he would experience from ceding control of the use to defendant, and evidence of out-of-pocket losses or of interrupted profits may be available. In addition, defendant's profits may reflect profits the plaintiff could have earned but for the unauthorized use. ${ }^{\theta 6}$ Where the injury suffered by plaintiff is small, it is likely that the market price that he would have demanded is small, and that a transfer to defendant would have taken place if there had been no "failed market" conditions. Not surprisingly, courts are much more likely to find fair use where the injury to plaintiffs is small. ${ }^{97}$

When a court weighs plaintiff's loss against the benefit of defendant's use, it is making a comparison similar to that made by the participants in market transactions. ${ }^{98}$ It may be said, then, that fair use implies the consent of the copyright owner by looking to whether the owner would have consented under ideal market conditions. Dean Prosser notes that the locution of "implied consent" is used in the law of intentional torts even where "consent does

94. See infra notes $163-75$ and accompanying text.

95. See generally Meeropol v. Nizer, 560 F.2d 1061, 1069-71 (2d Cir. 1977) (discussing purpose and necessity of use), cert. denied, 434 U.S. 1013 (1978); Williams \& Wilkins Co. v. United States, 487 F.2d 1345 (Ct. Cl. 1973) (value of medical research) (discussed supra notes 249 . 88 and accompanying text), aff'd by an equally divided Court, 420 U.S. 376 (1975) (per curiam); Elsmere Music, Inc. v. NBC, 482 F. Supp. 741, 745-47 (S.D.N.Y.) (discussing valid parody as fair use), aff'd, 623 F.2d 252 (2d Cir. 1980); Time, Inc. v. Bernard Geis Assocs., 293 F. Supp. 130, 145-46 (S.D.N.Y. 1968) (finding "a public interest in having the fullest information available on the murder of President Kennedy").

Intuitive estimates may often be required because of overall imperfections in the market structure, see infra note 96 , though reference to prices may provide useful constraints for this intuition.

96. The 1976 Copyright Act reflects both these elements in its damages provision: "The copyright owner is entitled to recover the actual damages suffered by him or her as a result of the infringement, and any profits of the infringer that are attributable to the infringement and are not taken into account in computing the actual damages." 17 U.S.C. § 504(b) (1976). See also cases cited supra note 95 .

Note, however, that insofar as the overall market remains imperfect, actual prices and profits might not accurately reflect social desirability, even if that desirability is measured solely in economic terms. See E. Mansfield, supra note 65, at 334 (discussing "theory of the second best"). Therefore, although such criteria can provide a court with usefully objective guides for its inquiry into public interest, they might not be determinative.

97. See, e.g., Triangle Publications, Inc. v. Knight-Ridder Newspapers, Inc., 626 F.2d 1171, 1177-78 (5th Cir. 1980); Williams \& Wilkins Co. v. United States, 487 F.2d 1345, 1357-59, 1362-63 (Ct. Cl. 1973), aff'd by an equally divided Court, 420 U.S. 376 (1975) (per curiam); Time, Inc. v. Bernard Geis Assocs., 293 F. Supp. 130, 146 (S.D.N.Y. 1968). See also 17 U.S.C. § 107 (1976) ("In determining whether the use made of a work in any particular case is a fair use the factors to be considered shall include - . . . (4) the effect of the use upon the potential market for or value of the copyrighted work."). Nimmer calls market effect the "central fair use factor." 3 M. Nimmer, Nimmer on Copyright § 13.05 [A][4], at 13-64 (1982) (footnote omitted).

98. See R. Posner, supra note 33, at 3-12. 
not exist, and there is no act which indicates it." 99 As an example of such implied consent, Dean Prosser refers to the plaintiff who undergoes an emergency operation while unconscious. There the surgeon who operates to save the plaintiff's life is not guilty of a battery because the plaintiff's consent to the operation "is 'implied' under the circumstances." 100 To justify imposing consent on the patient, Dean Prosser suggests the following explanation: "[T]he defendant is privileged because he is reasonably entitled to assume that, if the patient were competent and understood the situation, he would consent . . . "101 Thus, Dean Prosser has chosen a hypothetical condition relevant to the ultimate issue of consent in the context of battery: what would the patient consent to "if he were competent" rather than unconscious?

Are there any such hypothetical conditions relevant to the ultimate issues in copyright law? This Article suggests that the perfect market assumptions provide a guide to such conditions, because it is only in a functioning market that consensual transfers will lead to socially desirable resource use. ${ }^{102}$ Are there any exigencies-such as the imminence of an unconscious patient's death-that will justify resort to hypothetical consent instead of relying solely on a plaintiff's actual consent? This Article suggests that market failure creates such an exigency because, when market failure is present, it is impossible or undesirable to make dissemination of creative works depend solely on actual consent. Thus, where transfers will not occur because of market failure, courts should ask what the copyright owner would have consented to if he and the user had bargained in a functioning market situation. It might be argued that the copyright owner should receive compensation for the use in the same way that the patient receives the benefit of the operation. However, implied consent here serves to indicate that the social welfare is served, while in the example of the medical patient it served to indicate that individual welfare is

99. W. Prosser, Handbook of the Law of Torts $\S 18$, at 103 (4th ed. 1971) (footnote omitted).

100. Id. at 103.

101. Id.

102. If one would consent to a situation, it is arguably "fair" to impose that situation when obtaining actual consent is costly or impossible. As a member of society, the copyright owner shares in the cost savings effected by eliminating the need for actual consent in certain situations. See, e.g., Michelman, supra note 38, at 1176-81 ("to insist on full compensation to every interest which is disproportionately burdened by a social measure dictated by efficiency would be to call a halt to the collective pursuit of efficiency"). Moreover, since an additional branch of the fair use test protects against substantial injury, see infra notes 104-24 and accompanying text, the copyright owner has some protection against the possibility that he will be harmed more than benefited in the long run.

Consider the relation between procedure, fairness, and substantive result discussed in $\mathrm{J}$. Rawls, A Theory of Justice (1971), particularly in chapters 1-3 (considering what principles persons under certain hypothetical conditions would consent to adopt). For an excellent discussion of the many meanings that "consent" can take in political analysis, see Pitkin, Obligation and Consent-I, 59 Am. Pol. Sci. Rev. 990 (1965), and Pitkin, Obligation and Consent-II, 60 Am. Pol. Sci. Rev. 39 (1966).

"Consent" has had a role in fair use commentary. See, e.g., Studies Prepared for the Subcomm. on Patents, Trademarks and Copyrights of the Senate Comm. on the Judiciary, Fair Use of Copyrighted Works 15, 86th Cong., 2d Sess., (Study No. 14) (Comm. Print 1960) [hereinafter cited as Latman Study]. 
served; further, implied consent is only the second stage of a three-part inquiry. The third stage of the inquiry has a direct concern with the economic welfare of the copyright owner. ${ }^{103}$

\section{The Third Element of the Test: The Substantial Injury Hurdle}

The third and final part of the test is designed to maintain the appropriate balance between the incentive and dissemination interests discussed earlier. Fair use should be denied whenever a substantial injury appears that will impair incentives.

1. Complete Market Failure. When no incentive purpose would be served by giving plaintiff protection, and where no disincentive would be created by allowing defendant free use, logic suggests that the courts should then allow fair use. ${ }^{104}$ Assume, for example, that prohibitively high transaction costs obtain in a particular area of use, so that copyright owners and potential users find that the costs of locating and bargaining with each other exceed whatever profit they might expect to gain from the transaction. Under such circumstances, no transactions will occur. Therefore, enforcement of market entitlements would not benefit the copyright owner, and would certainly harm the potential copyright user who is denied access, as well as those who might benefit from the use. Given the presence of a complete market failure here, judicial refusal to enforce the owner's right of control may be the only way to allow use of the work. ${ }^{105}$ And since a refusal to enforce in these circumstances would not deprive the owner of any revenues he would otherwise receive, there is no injury to incentives that might militate against a grant of fair use.

2. Intermediate Cases of Market Failure. In cases of complete market failure, fair use appears to be justified upon satisfaction of the first two parts of the fair use test, i.e., identification of market failure and determination that there is a net social benefit from allowing defendant's use. There may also be intermediate cases of market failure, however, where the market cannot be relied upon to generate all desirable exchanges, but where some such transactions would be possible. In such instances, giving fair use to a class of users would enable some persons who would otherwise purchase the use to obtain that use for free. Thus fair use could cause some injury to relevant incentives because, for some users, fair use would substitute for purchase. ${ }^{106}$ The first two parts of the test would no longer serve to accommodate the competing interests.

In instances of intermediate market failure, both enforcement (a finding of infringement) and nonenforcement (a finding of fair use) have dangers.

103. The impact on aggregate value caused by the immediate transfer is only part of the relevant inquiry.

104. See also Comment, Photocopying and Fair Use: An Examination of the Economic Factor in Fair Use, 26 Emory L.J. 849, 865-71 (1977).

105. In appropriate cases, awarding the plaintiff a damage remedy may also allow the user continued access to the work. See infra notes $125-34$ and accompanying text.

106. Damage by substitution is of course the damage to which the fair use criteria are most sensitive. See, e.g., M. Nimmer, supra note 97 , § 13.05[B], at 13-65 to 13-72. 
The danger from enforcement is that desirable transfers may be prevented. The danger from giving fair use is that incentives may be undermined. To resolve the conflict, the defendant seeking fair use treatment should be required to surmount an additional hurdle: fair use should be denied if it would leave the plaintiff copyright owner facing substantial injury to his incentives. ${ }^{107}$

The third branch of the test diverges from the negligence model summarized earlier. ${ }^{108}$ In negligence, the decision as to the wrongfulness of defendent's conduct usually depends on a comparison of costs and benefits; if the cost of defendant's precautions would have been greater than the decrease in accident costs produced, then the defendant is not negligent for having declined to take the precautions. ${ }^{109}$ The absolute level of damages caused by the accident under that kind of analysis is irrelevant. ${ }^{110}$ Under the third part of this fair use test, however, fair use will be denied if a substantial level of injury, judged on an absolute scale, would be generated by defendant's use, even if the comparison of injury and benefit showed that defendant's use would have created a net social benefit.

The substantial injury hurdle serves several functions. First, it preserves the incentive system at the core of copyright. Second, it reflects a recognition that judgments the courts make about whether a defendant's use is valuemaximizing are rough approximations. ${ }^{111}$ The substantial injury hurdle provides some additional protection for copyright owners against the possibility of a bad estimation. ${ }^{112}$ Third, awarding copyright owners a veto whenever their injury is substantial gives some guarantee that the fair use system will not put them at an intolerable disadvantage. Even if authors are viewed solely as instruments of social good, ${ }^{113}$ their demoralization as individuals will decrease the production of valuable works. ${ }^{114}$ The substantial injury hurdle can also help courts avoid the danger of making otherwise curable market failures permanent through the grant of fair use. To explain this last function more fully, it is necessary to look at the nature of the relevant injury.

107. This hurdle serves not only to protect the individual copyright owner from substantial loss but to protect society as a whole from erosion of the copyright system. Compare the function of the "just compensation" guarantee as discussed in Michelman, supra note 38 .

108. See supra notes 55-58 and accompanying text.

109. Id.

110. Broader economic views of accident law might, however, take a different view. See G. Calabresi, supra note 55, at 39-67 (exploring modes of spreading heavy losses).

111. See Calabresi \& Melamed, supra note 38 , at 1106-10.

112. Where Congress has elected to give copyright owners a property right in the first instance, doubts should be resolved in the owner's favor.

113. Although the dominant view is clearly that authors receive their property right for a larger social purpose, Congress has shown special solicitude for the the welfare of individual authors, even as opposed to publishers and other potential owners of copyright. See 17 U.S.C. $\S \S$ 203, 304(c) (1976) (termination rights); House Report, supra note 10, at 140, reprinted in 1976 U.S. Code Cong. \& Ad. News at 5756 ("the author, who is the fundamental beneficiary of copyright under the Constitution," is given the right to terminate grants that he may have made to publishers and other assignees; made-for-hire works not terminable). costs).

114. See also Michelman, supra note 38, at 1177-80, 1208-24 (discussing demoralization 
Injury is relevant to both the second and third parts of the fair use test, but different types of injury are relevant to each part. On the question of balancing plaintiff's harm against defendant's benefit, courts should look to the injury caused to the copyright owner by the specific use made by defendant. The narrow inquiry reveals whether transferring the use to the defendent gives rise to a net social benefit. In order to prevent substantial injury to incentives, however, the court should also inquire into the extent of the losses likely to follow in the market as a whole from a grant of fair use, ${ }^{115}$ both from this defendant and from other similarly situated persons. When a determination is made that a certain kind or practice of use is "fair," the practices of persons other than the specific defendant may be affected. As the Senate Report to the 1976 Copyright Act states, "Isolated instances of minor infringements, when multiplied many times, become in the aggregate a major inroad on copyright that must be prevented." 116 Thus, the inquiry into substantial injury should include consideration of cumulative harm. ${ }^{117}$

This inquiry should also include harm that has not yet occurred but is likely to occur. ${ }^{118}$ Both the loss of revenues anticipated under the market structure prevailing at the time of suit, and the loss of those revenues that would be generated under whatever market structure would follow upon a grant of infringement, should be relevant. ${ }^{119}$ For example, transaction costs to obtain permission to use certain materials might be prohibitively high at one point in time, yet in some circumstances a clearinghouse system might be set up to simplify the process of purchasing permission and thus allow a market to function. To award fair use without regard to the possibility of imminent change in the market structure might be to make permanent an otherwise curable market failure and thus potentially to insulate a new and valuable use from the stimulus of consumer demand.

Whether a market failure is curable, and whether such a cure would follow upon a finding of infringement and generate substantial revenues, are difficult factual questions. They must, however, be faced; the courts should limit their grants of fair use to those occasions in which the market cannot be

115. See also M. Nimmer, supra note $97, \S 13.05[A][4]$, at $13-64$ to $13-65$ (effect of the use upon the [plaintiff's] potential market "poses the issue of whether unrestricted and widespread conduct of the sort engaged in by the defendant . . . would result in a substantially adverse impact on the potential market for or value of the plaintiff's work"); id. § 13.05[E][4][c], at 13-84.

116. Senate Report, supra note 26 , at 65.

117. See supra note 115 .

118. Cf. Williams \& Wilkins Co. v. United States, 487 F.2d 1345, 1359 (Ct. Cl. 1973) (finding, inter alia, large-scale library photocopying was not proven to be detrimental to the circulation and future commercial value of plaintiff's medical journals), aff'd by an equally divided Court, 420 U.S. 376 (1975) (per curiam); Time, Inc. v. Bernard Geis Assocs., 293 F. Supp. 130, 146 (S.D.N.Y. 1968) (finding no significant potential for future injury to the value of the Zapruder films of the Kennedy assassination caused by the unlicensed publication of sketches of the key frames in a book advancing a novel theory about the assassination); M. Nimmer, supra note 97, $\S 13.05[\mathrm{~A}][4]$, at 13-65 (courts should look at conduct regardless of "whether in fact engaged in by defendant or others"); id. $\S 13.05[E][4][c]$, at 13-84 ("all potential defendants").

119. Discussion about what market structure would follow from a judgment of liability will necessarily involve a judgment of probabilities. 
relied upon to allow socially beneficial uses to occur. This point is particularly important for new technologies, such as photocopying ${ }^{120}$ and videotaping. ${ }^{121}$ When a new use for copyrighted works becomes available to the public, market mechanisms may take time to develop. At early stages of use, the transaction costs that would be involved for a user to purchase permission to use, or for the copyright owner to seek enforcement against nonpaying users, might well exceed whatever gain the parties might otherwise expect from the transaction. A custom therefore may develop under which users proceed without permission. ${ }^{122}$

As the quantity of use grows, the copyright owners may wish to set up collection and enforcement mechanisms, including such market devices as clearinghouses. ${ }^{123}$ In order to persuade users to proceed through the device, however, the copyright owners might well need a judicial declaration that the uncompensated use, previously minor and left unfettered, constituted an infringement of copyright. Such owners would be able to make a showing of substantial injury only if a court were willing to consider whether substantial revenues would follow after a finding of infringement.

The risk from granting fair use without reference to such probable injury should be obvious. New technologies will make certain copyrighted works more valuable, as, for example, the invention of cinema increased the value of those books suitable for adaptation to the screen. If copyright protection is denied because of an otherwise curable market failure, then the additional revenues that would have flowed from the new technological use will not appear. If the authors' revenues fail to reflect the additional value that new technology gives to such works, then insufficient resources may be drawn into their creation. To argue that copyright owners need receive no compensation for additional uses of their works ${ }^{124}$ would overlook the possibility that such

120. Photocopying was at issue in Williams \& Wilkins Co. v. United States, 487 F.2d 1345 (Ct. Cl. 1973), aff'd by an equally divided Court, 420 U.S. 376 (1975) (per curiam), discussed infra text accompanying notes 249-88. Williams \& Wilkins Co. has evoked substantial scholarly comment. See, e.g., M. Nimmer, supra note 97, § 13.05[E][4][c]-[e], at 13-82 to 13-92; Perlman \& Rhinelander, supra note 81.

121. Home videotaping of on-the-air television programs is of course the issue in the Betamax case, Universal City Studios, Inc. v. Sony Corp. of America, 480 F. Supp. 429, 435 (C.D. Cal. 1979), rev'd in part and remanded, 659 F.2d 963 (9th Cir. 1981), cert. granted, 102 S. Ct. 2926 (1982) (No. 81-1687), discussed infra text accompanying notes 289-322. The district court decision in the case has been extensively discussed. See, e.g., Note, Universal City Studios, Inc. v. Sony Corp.: "Fair Use" Looks Different on Videotape, 66 Va. L. Rev. 1005 (1980); Note, The Betamax Case: Accommodating Public Access and Economic Incentive in Copyright Law, 31 Stan. L. Rev. 243 (1979) [hereinafter cited as Stanford Note].

122. Compare the view of custom presented herein with Rosenfield, Customary Use as "Fair Use" in Copyright Law, 25 Buff. L. Rev. 119 (1975).

123. See, e.g., the discussion of the form and function of clearinghouses in Hampton, Clearing House as Optimum Solution to Copyright Problems Affecting Communication of Educational and Scientific Information, in Reprography and Copyright Law 189 (L. Hattery \& G. Bush eds. 1964).

124. Rosenfield argues that in the context of fair use, a copyright owner should be prevented "from seeking a greater monopoly than he would have had with the earlier systems of reproducing copies." Rosenfield, supra note 122 , at 122.

Rosenfield also argues that the custom of nonpayment, see infra notes 224-33 and accompa- 
compensation may change the patterns of production in a desirable way. Stimulation of such response is, after all, a basic goal of copyright law.

\section{Alternatives to Fair Use}

Although this Article has advocated the three-part test as a useful approach for resolving the conflict between the incentive and dissemination goals of copyright law, other market-oriented approaches may also be useful in achieving this goal. For example, when the cause of the market failure lies in high transaction costs, economics does not dictate a choice solely between awarding fair use or giving the copyright owner complete control through injunction and damages. Instead, if the law permits, the court might choose to refuse an injunction yet grant the copyright owner monetary relief. ${ }^{125} \mathrm{~A}$ monetary remedy could largely obviate any threatened injury.

nying text, is an independent justification for fair use, because, inter alia, "the law loses credibility with the public" if "a teacher, researcher or scholar may lawfully copy for his private, non-profit use only under conditions of maximum inefficiency in the use of technology, time and resources." Id. at 136 (footnote omitted) (discussing photocopying). There is some merit in Rosenfield's credibility argument. United States Representative Stanford Parris of Virginia, for one, has termed the Ninth Circuit's Betamax decision as "the latest example of idiocy in the federal judiciary," Fortune, Feb. 1982, at 126, and humorists have poked considerable fun at the image of persons being arrested in their homes for misusing their living-room videorecorders. However, arguments premised on custom and expectation can easily be drawn too far. Among other things, the circumstances that gave rise to the custom can be changed; the ridicule that the Betamax result has occasionally drawn in the popular press might have been avoided if the Ninth Circuit Court of Appeals had focused on whether the courts could so change the economic arrangements that enforcement would not necessitate impractical court actions against each individual user. Of course, this might be implicit in the posture of the case. The only individual home user who was named as a defendant in the Betamax was not a real target of that litigation; rather he was "a client of plaintiffs' law firm" who "consented to being a defendant," and against whom plaintiffs had "waived any claim for damages or costs." Universal City Studios, Inc. v. Sony Corp. of America, 480 F.Supp. 429, 437 (C.D. Cal. 1979), rev'd in part and remanded, 659 F.2d 963 (9th Cir. 1981), cert. granted, 102 S. Ct. 2926 (1982) (No. 81-1687). Nevertheless, the popular perception of the case was probably quite influenced by the Ninth Circuit's refusal to make consideration of relief (i.e., whether changes in the technology or market structure would occur to make user fees easy to collect in a nonintrusive manner) part of its consideration of liability. See generally the discussion of the Betamax case infra text accompanying notes 289-322.

125. Calabresi and Melamed, in their seminal article, Property Rules, Liability Rules, and Inalienability: One View of the Cathedral, supra note 38, made it clear that the law has many choices, not only as to who should possess an entitlement, but also as to how such an entitlement should be protected. The modes of protection include "property rules" such as injunctive remedies, and "liability rules" such as damage remedies. When the owner's entitlement is protected by property rules, he may sell his right at a price of his choosing, or may refuse to sell. But when his entitlement is protected by liability rules, the owner may not preveht an involuntary transfer; rather he will be permitted to collect a court determined price (i.e., damages) for the value of the rights he has lost. Calabresi and Melamed write:

An entitlement is protected by a property rule to the extent that someone who wishes to remove the entitlement from its holder must buy it from him in a voluntary transaction in which the value of the entitlement is agreed upon by the seller. . . [O]nce the original entitlement is decided upon, the state does not try to decide its value. . . .

Whenever someone may destroy the initial entitlement if he is willing to pay an objectively determined value for it, an entitlement is protected by a liability rule. Id. at 1092 (footnote omitted). The grant of monetary relief in place of an injunction for copyright infringement would be an example of a liability rule. Whether the copyright law permits 
It may be costly to society to give an author injunctive control over a work in a market failure situation since that might completely prohibit a defendant's use. ${ }^{126}$ Enforcement limited to a damage remedy, award of profits, or reasonable royalty ${ }^{127}$ might provide a mechanism for transferring revenues from user to author while simultaneously allowing utilization of the work. Such a court-dictated transfer might carry far less economic and social cost than would rules that force a choice between forbidding all involuntary transfers or leaving involuntary transferors without a remedy. By imposing a "price" for the use, the court award might itself "cure" market failure. ${ }^{128}$

It may be asked, however, whether courts should abandon the traditional all-or-nothing choice between enforcement and fair use bequeathed to them by fair use precedent. There are limitations on judicial expertise; whether the courts themselves are the apprcpriate institutions to "cure" market failure by inventing methods of compulsory transfer or by setting copyright prices is a very real question. ${ }^{129}$ Further, an objectively determined "price" is always less satisfactory to a property owner than a price of his own choosing and is usually a less reliable indicator of value for society's purposes as well. ${ }^{130}$ Were the courts to feel free to substitute one for the other, an accelerating erosion of the market system could be triggered. From the point of view of copyright owners (and thus from the point of view of society's need to maintain overall incentives), a system that permitted certain limited uncompensated takings to occur, as long as they did not cause substantial injury, might be preferable to a system in which compensation was guaranteed but only after the fact.

In addition, copyright law has traditionally made compulsory licenses (the equivalent of "reasonable royalty" determinations) a matter for legislative action. ${ }^{131}$ Compulsory licenses have been hard-fought political issues, ${ }^{132}$

the substitution of a liability rule for a property rule is a matter of debate. See, e.g., Nimmer, copyright liability for Audio Home Recording: Dispelling the Betamax Myth, 68 Va. L. Rev. 1505, 1530-31 (1982) (arguing in favor of court-imposed royalty).

126. Although a bargain can often be struck in which enjoined parties pay those holding the injunction to let them proceed, market failure may make this impossible in a given case. See Calabresi \& Melamed, supra note 38, at 1118-19.

127. Such alternatives have been widely discussed. See, e.g., M. Nimmer, supra note 97 , § 13.05[E], at 13-91 to 13-92; Timberg, A Modernized Fair Use Code for the Electronic as Well as the Gutenberg Age, 75 Nw. U.L. Rev. 193, 233-44 (1980); Stanford Note, supra note 121, at 257-62.

128. See supra notes $125-27$.

129. The Williams \& Wilkins court questioned the judiciary's abilities and authority in this regard. See infra notes $271 \& 273$.

130. See sources cited supra note 59.

131. Compulsory licenses appear at, e.g., 17 U.S.C. §§ 111(d) (Supp. IV 1980) (cable television), id. $\$ 115$ (phonorecords), id. § 116 (jukeboxes). A Copyright Royalty Tribunal has been created, inter alia, to review and adjust statutory royalty rates. Id. $\S 801$. The courts' role in reviewing such rates is limited. Id. $\S 810$ (judicial review). An exception to this general approach appears in the 1976 Copyright Act in regard to innocent infringements that may be traced to the copyright holder's omission of a notice of copyright. The omission of notice may itself cause market failure, for a potential user would not know copyright is claimed. See supra text accompanying note 74. Congress has given the courts in that context the power to impose a reasonable license fee as a condition to continued use of the copyrighted materials. Id. § 405(b).

132. See, e.g., Staff of Senate Comm. on the Judiciary, 86th Cong., 1st Sess., Copyright Law Revision Studies pts. 5-6 (Comm. Print 1960). See also House Report, supra note 10, at 175-78 (compulsory licensing provisions for cable television). 
for whose resolution Congress would appear to provide the most appropriate forum. Thus, although judicial regulation of copyright markets is not unknown, ${ }^{133}$ and although Congress is often slow to act in this area, ${ }^{134}$ it may be unwise to advocate judicial adoption of an alternative to fair use that asks courts essentially to restructure markets or to set prices for the use of copyrighted material.

\section{E. Burden of Proof}

Much debate today centers on whether the defendant or plaintiff should have the burden of proving injury. ${ }^{135}$ The copyright statute does not state where the burden of proving injury or any other fair use factor should be placed, and Congress apparently preferred to leave this issue to the courts. ${ }^{130}$

133. See A. Latman \& R. Gorman, supra note 19, at 455-58 (discussion of the protracted antitrust litigation, brought by the government and CBS against the licensing practices of ASCAP and $\mathrm{BMI}$ ). The result of these judicial proceedings has been a series of consent decrees. Id.

134. The 1909 Copyright Act survived with only piecemeal revisions until 1976. A draft bill for the comprehensive revision that became the 1976 Act was first introduced in both houses in 1964. See House Report, supra note 10, at 47-50. However, it should be noted that Congress may act more quickly in response to the Betamax controversy; bills have been submitted and hearings have been held. See, e.g., 24 Pat. Trademark \& Copyright J. (BNA) 577-78 (Oct. 7, 1982).

135. There is a substantial disagreement among the scholars about the nature and allocation of the burden of proving injury in fair use litigation. See, e.g., M. Nimmer, supra note $97, \S$ 13.05[E][4][C], at 13-82 to 13-86; Comment, supra note 104, at 869-84.

The courts also disagree about the character of this burden. In Williams \& Wilkins for instance, the court wrote:

To us it is very important that plaintiff has failed to prove its assumption of economic detriment, in the past or potentially for the future. One of the factors always considered with respect to "fair use," ... is the effect of the use on the owner's potential market for the work. This record simply does not show a serious adverse impact, either on plaintiff or on medical publishers generally, from the photocopying practices of the type of NIH [National Institutes of Health] and NLM [National Library of Medicine]. In the face of this record, we cannot mechanically assume such an effect, or hold that the amount of photoduplication proved here "must" lead to financial or economic harm. This is a matter of proof and plaintiff has not transformed its hypothetical assumption, by evidence, into a proven fact.

Williams \& Wilkins Co. v. United States, 487 F.2d 1345, 1359 (Ct. Cl. 1973), aff'd by an equally divided Court, 420 U.S. 376 (1975) (per curiam).

Similarly, the district court in the Betamax case noted that "plaintiffs ask the court to find harm." Universal City Studios, Inc. v. Sony Corp. of America, 480 F. Supp. 429, 451 (C.D. Cal. 1979), rev'd in part and remanded, 659 F.2d 963 (9th Cir. 1981), cert. granted, 102 S. Ct. 2926 (1982) (No. 81-1687). By contrast, the Ninth Circuit rejected this approach to allocating the burden: "[Proof of actual damages] is simply too great a burden to impose on copyright plaintiffs." Universal City Studios, Inc. v. Sony Corp. of America, 659 F.2d 963, 974 (9th Cir. 1981), cert. granted, 102 S. Ct. 2926 (1982) (No. 81-1687). See also Encyclopedia Britannica Educational Corp. v. Crooks, 447 F. Supp. 243, 251 (W.D.N.Y. 1978) ("[T] he burden of establishing fair use is on the defendant and . . . the plaintiff in a copyright case is presumed to suffer irreparable injury.").

136. The 1965 copyright revision bill had a fair use section that provided, in its entirety, that "the fair use of a copyrighted work is not an infringement of copyright." Although this early version of $\S 107$ more than quadrupled in length on its way to enactment in 1976, the basic characterization did not change. 17 U.S.C. $\$ 107$ (Supp. IV 1980). The Register of Copyrights said about the early § 107:

The author-publisher interests have suggested that fair use should be treated as a defense, with the statute placing the burden of proof on the user. The educational group has urged just the opposite, that the statute should provide that any nonprofit use for 
A market approach can provide some insight into how the burden of proof should be allocated.

As discussed earlier, ${ }^{137}$ the copyright law appears to be premised on the assumption that functioning markets exist for copyright works. When such markets exist, injury will normally follow upon infringement and, even if the precise dimensions of that injury are hard to prove, it makes sense that lack of explicit proof of injury will be excused. ${ }^{138}$ The congressional decision to provide plaintiffs the option of minimum statutory damages ${ }^{139}$ reflects this sentiment and suggests that the plaintiff should have no initial burden of disproving fair use. ${ }^{140}$ Instead, the defendant should have the initial burden of proving that market failure exists and that it will continue to exist even if a judgment of liability were to be tendered. In addition, if his use serves no social purpose, then he could not satisfy the second part of the fair use test and further consideration of his fair use claim would be unwarranted. Therefore, he also should be required to prove that his use serves some social purpose, ${ }^{141}$ and to demonstrate the nature and extent of the public interest that is served. ${ }^{142}$

educational purposes is presumed to be a fair use, with the copyright owner having the burden of proving otherwise. We believe it would be undesirable to adopt a special rule placing the burden of proof on one side or the other. When the facts as to what use was made of the work have been presented, the issue as to whether it is a "fair use" is a question of law. Statutory presumptions or burden-of-proof provisions could work a radical change in the meaning and effect of the doctrine of fair use. The intention of section 107 is to give statutory affirmation to the present judicial doctrine, not to change it.

Register of Copyrights, 89th Cong., 1st Sess., Supplementary Report of the Register of Copyrights on the General Revision of the U.S. Copyright Law: 1965 Revision Bill 28 (Comm. Print 1965).

137. See supra notes $62-87$ and accompanying text.

138. See Nimmer, supra note 9 , at 1053.

139. Section 504(c) of 17 U.S.C. (Supp. IV 1980) provides plaintiffs the option of electing statutory damages in lieu of proving actual damages in an infringement action. The election of statutory damages may be made at any time before judgment is entered. Id. By electing statutory damages, the copyright owner may recover between $\$ 250$ and $\$ 10,000$ for any one infringement by any one infringer, the sum to be determined by the court. Id. $\S 504(\mathrm{c})(1)$. Greater or lesser amounts may be awarded in certain circumstances. Id. $\$ 501(\mathrm{c})(2)$. According to Nimmer, this statutory damage option is made available because "[i]t is inherently difficult in copyright infringement actions for a plaintiff to prove actual damages as against a given defendant." Nimmer, supra note 9, at 1053 .

140. See Nimmer, supra note 9.

141. Since defendant is a member of society, ordinarily his use will have some social value. This will not always be true, however. One case in which the defendant's use had no apparent social value is Amana Refrigeration, Inc. v. Consumers Union, Inc. 431 F. Supp. 324 (N.D. Iowa 1977). Amana, in an effort to counteract a critical Consumer Reports appraisal of its microwave ovens, had published a brochure featuring a full paragraph from an earlier, more favorable, Consumer Reports evaluation. Consumers Union requested that Amana withdraw the brochure and Amana responded by bringing an unfair trade practice claim. Consumers Union defended on the ground that the brochure was deceptive, and counterclaimed that Amana had violated the Consumer Reports copyright. Finding that in publishing the brochure Amana "was attempting to convey the impression that [Consumers Union] approved of [Amana's] microwave oven as of 1973 when the exact opposite was true," id. at 326, the court dismissed Amana's defense of fair use to the counterclaim and issued in injunction barring any further distribution of the brochure. Id. at 327.

142. Even when defendant's use has some social value, that value must be significant enough to outweigh plaintiff's injury. See supra notes $92-103$ and accompanying text. 
When severe market failure is present, injury to the copyright owner may not follow from infringement. ${ }^{143}$ If the proof of severe market failure offered by the defendant leads the court to doubt that injury will be present, it is legitimate for the court to demand evidence from the copyright owner that such injury would indeed follow. The burden of going forward with proof of injury should then shift to plaintiff. The harm he has suffered or anticipates is an area that should be peculiarly within plaintiff's knowledge. ${ }^{144}$

Fair use has been variously regarded as a "defense," 145 as a "privilege," 146 or as a use that is noninfringing. ${ }^{147}$ Given the ambiguous nature of fair use, it might be argued that the court could appropriately demand some proof of injury from plaintiff even in the first instance. ${ }^{148}$ This Article does not go so far; it suggests that, on a case-by-case basis, a court should ask plaintiff to come forward with evidence of probable harm when the court has drawn an inference, from defendant's proof of market failure or from other sources, that no injury is likely. Moreover, since it is defendant who seeks to show that the conditions of his use are so unlike those contemplated by the copyright scheme that fair use is warranted, the ultimate burden of persuasion on this issue should rest with him.

\section{F. Summary}

An analysis of the economic functions served by copyright and of the internal dynamics of the copyright statute has suggested a three-part test for fair use: first, does a reason to mistrust the market appear?; second, is the transfer to defendant value-maximizing, as determined by weighing plaintiff's injury against defendant's social contribution?; third, if both the first and second conditions are satisfied, would a grant of fair use cause substantial injury? If it would not, and if the prior conditions are satisfied, then fair use should be awarded. Defendant user should prove the existence of market failure and the social merit of his use. If defendant meets these burdens and

143. See infra note 221 (relation between types of injury and fair use).

144. A particular party's access to proof on an issue is, of course, often advanced as a reason for putting the burden as to that issue on him. See, e.g., Comment, supra note 104, at 869.

145. See, e.g., Meeropol v. Nizer, 417 F. Supp. 1201, 1213 (S.D.N.Y. 1976), rev'd on other grounds, 560 F.2d 1061 (2d Cir. 1977), cert. denied, 434 U.S. 1013 (1978).

146. See, e.g., Rosemont Enters., Inc. v. Random House, Inc., 366 F.2d 303, 304, 306-07 (2d Cir. 1966), cert. denied, 385 U.S. 1009 (1967). See also Cohen, Fair Use in the Law of Copyright, 6 ASCAP Copyright L. Symp. 43, 45-48 (1955).

147. See Cohen, supra note 146; Comment, supra note 104, at 871-75. Section 107 provides that fair use "is not an infringement of copyright." 17 U.S.C. § 107 (Supp. IV 1980). See supra note 136 .

148. In a suit for unintentional torts, the plaintiff has to show that defendant's acts were wrongful and that he (plaintiff) was injured. It can be argued that fair use acts as a repository for these elements of a plaintiff's cause of action when market failure calls into question whether the user justifiably bypassed the market and whether injury occurred. See supra text accompanying notes 55-61.

See also Comment, supra note 104 , at 869 , which argues that harm from photocopying is improbable and courts should therefore require plaintiffs to prove economic injury in the photocopying context. 
raises a significant doubt as to whether harm is likely, then plaintiff should come forward with a showing of injury.

If the market failure in a given case is likely to be cured (and substantial revenues generated) by the parties' own actions following a finding of infringement, fair use should be denied. However, if the only possible "cure" is through a complex, court-imposed structure of monetary remedies and limited injunctive relief, both fair use tradition and the inherent limitations of the judicial process suggest that the court should hesitate before attempting such a task. It may be appropriate to leave the responsibility for restructuring the parties' economic relationships to the parties or to Congress. Analytically, however, it should be recognized that the market considerations underlying the three-part test could trigger a damage remedy or market restructuring, rather than fair use, in a court that is inclined to engage in such intervention.

The three-part test proposed here, while not previously articulated in so many words, reveals itself in many of the decisions reached by the courts in the copyright area, and, as will be seen, serves to unify the various factors that courts and the statute have made relevant to fair use determinations. The remainder of this Article will explain how this test finds expression in the cases and statute, will analyze the Williams \& Wilkins opinion, which gave the fullest expression to the test, and will examine how the Betamax court could have proceeded had it accepted these criteria.

\section{Evidence of a Market Approach in Existing Authorities}

This Article has suggested that a court will ordinarily not grant a defendant fair use treatment unless the facts of the case give reason to mistrust the market. ${ }^{149}$ This section will review cases and authorities in which recurring patterns of such mistrust appear to have guided courts in the fair use area. The discussion will show that courts and, in following their lead, Congress, have at times grappled with a market approach, that such an approach is reflected in the traditional fair use factors, and that, were the courts to embrace the market approach more fully, a more effective and consistent use of the traditional factors would result.

\section{A. Inquiries Into Market Breakdown Under the Traditional Fair Use Ap- proach}

1. Market Barriers: New Technologies and Other Applications. As previously discussed, the impossibility or difficulty of achieving a market bargain is a factor that may justify a grant of fair use. The relevance of market barriers to fair use is implicitly reflected in the legislative history of section 107 of the Copyright Act. The Senate Report to the new copyright act states that "[a] key, though not necessarily determinative, factor in fair use is whether or not the work is available to the potential user," 150 so that the out-of-print status

149. See supra text accompanying notes 89-91.

150. Senate Report, supra note 26, at 64 . 
of a copyrighted work may help to justify fair use. ${ }^{151}$ This is consistent with a market approach, since markets cannot form where goods are unavailable. ${ }^{152}$ Similarly, the Guidelines for Educational Fair Use in the House Report single out for fair use treatment instances of classroom photocopying in which bargains are particularly unlikely to occur because the teacher's use is spontaneous, individual and unsystematic. ${ }^{153}$ One of the prerequisites for making multiple copies under the Guidelines is that " $[t]$ he inspiration and decision to use the work and the moment of its use for maximum teaching effectiveness are so close in time that it would be unreasonable to expect a timely reply to a request for permission." 154

A particular type of market barrier is transaction costs. As long as the cost of reaching and enforcing bargains is lower than anticipated benefits from the bargains, markets will form. If transaction costs exceed anticipated benefits, however, no transactions will occur. ${ }^{155}$ Thus, the confluence of two variables is likely to produce a market barrier: high transaction costs and low anticipated profits. New technologies are likely to present both high transaction costs and, where uses by individual scholars or in individual homes are at issue, correspondingly low anticipated profits. This may explain why the "personal," "individual" nature of copying has been held relevant to fair use, ${ }^{156}$ and why "home use" may be relevant to the reach of copyright law. ${ }^{157}$ Consider, for example, the impact of the photocopy machine or the tape recorder. Each makes it possible for individuals to make use of copyrighted works in new and potentially valuable ways. From the point of view of the individual user, the anticipated "profit" is likely to be small, so his use will be

151. Id. In a given case, the out-of-print status of a work can trigger market failure, yet fair use would be inappropriate because allowing uncompensated use would injure the copyright owner's future market for a second printing. Recognizing the separability of the two issues to which out-of-print status can be relevant-the issue of market failure-can clarify some of the current ambiguity over the matter. Compare Senate Report, supra note 26, at 64, with, e.g., Meeropol v. Nizer, 560 F.2d 1061, 1070 (2d Cir. 1977) ("The fact that the Rosenberg letters have been out of print for 20 years does not necessarily mean they have no future market which can be injured."), cert. denied, 434 U.S. 1013 (1978).

152. See Triangle Publications, Inc. v. Knight-Ridder Newspapers, Inc., 626 F.2d 1171, 1176 n.14 (5th Cir. 1980) ("If the copyrighted work is out of print and cannot be purchased, a use may be more likely to prevail on a fair use defense.") (emphasis added) (citing Senate Report, supra note 26, at 64 (“'Availability of the work")).

153. See House Report, supra note 10, at 68-69.

154. Id. at 69.

155. Of course, if an outside party like the government bears the transaction costs, the parties will not be prevented from achieving their bargain, but an inordinate amount of transaction costs might then be imposed on society. While shifting the burden of transaction costs may be appropriate in some circumstances, the focus here instead should be on reducing these costs.

156. See, e.g., Williams \& Wilkins Co. v. United States, 487 F.2d 1345, 1355 (Ct. Cl. 1973) ("personal, individual focus" of the photocopy), aff'd by an equally divided Court, 420 U.S. 376 (1975) (per curiam). See also Twentieth Century Music Corp. v. Aiken, 422 U.S. 151 (1975) (small commercial establishment using home radio receiver to bring music to customers held not to be "performing" and thus not liable for copyright infringement).

157. The home use of audio tape recorders has been referred to as "fair use." See remarks of Rep. Kastenmeier quoted in Universal City Studios v. Sony Corp. of America, 480 F. Supp. 429, 446 (C.D. Cal. 1979), rev'd in part and remanded, 659 F.2d 963 (9th Cir. 1981), cert. granted, 102 S. Ct. 2926 (1982) (No. 81-1687). 
easily discouraged by transaction costs. Also, the technology's novelty may mean that the participants have no established market channels to rely on, so that the purchase of permission is likely to be cumbersome and expensive. High transaction costs and low per-transaction profits will converge. From the point of view of the copyright owner, the costs of enforcement against a diffuse group of individuals might outweigh anticipated receipts. A custom of use without payment will easily arise in such contexts unless the transaction costs of seeking permission or of enforcement are in some way reduced.

In such situations, transaction costs are likely to prevent at least some value-maximizing transfers from occurring ${ }^{158}$ if the copyright is enforced. At the extreme, enforcing the owner's rights might eliminate the use, and thus bring no income to the owner and deprive society of the benefit of the technology. For this reason, new technologies may become the subject of fair use treatment.

New technologies do not always involve market barriers, however, and thus do not always merit fair use consideration. In a case where a county educational program was videotaping educational television programs, the systematic and centralized nature of the copying and the various market alternatives that were present made license and purchase agreements quite possible. ${ }^{159}$ The court there denied fair use treatment at least in part because of this possibility. ${ }^{160}$ Thus it is the absence of a market and the prospect that such a market may form that is important, not the technological nature of the use.

The role of transaction costs also explains those cases that rely on the copyright owner's apparent or likely consent in granting fair use. ${ }^{161}$ Where a transfer is likely to be in the mutual interest of both owner and user, the courts

158. See, e.g., Breyer, The Uneasy Case for Copyright, supra note 63, at 316-18 ("[S]ome potential users, willing to pay royalties but unwilling to pay the transactions' costs, will not obtain the copyrighted item."). The discussion in text relates to a common point made by lawyereconomists. A market works to transfer resources to their highest-valued resources. R. Posner, supra note 33, at 1-13,27-31. Professor Coase has argued that when transaction costs are absent, it does not matter where the legal system assigns rights to the resources. Where transactions can be conducted costlessly, resources will gravitate naturally to those willing to pay the most for them, through a series of consensual exchanges. Coase, supra note 40 . When transaction costs are high, on the other hand, some economists argue that rights should be assigned so as to promote the allocation of resources to their highest valued use. See R. Posner, supra note 33, at 34-39. Where transaction costs may be quite high in relation to the gain to be anticipated from transfers, fair use operates to make sure that certain uses are placed (without need of purchase) in the hands of those who value them most.

159. Encyclopaedia Britannica Educational Corp. v. Crooks, 542 F. Supp. 1156, 1177-78 (W.D.N.Y. 1982).

160. The availability of the copyrighted works was one of the key grounds used by the court to distinguish Williams \& Wilkins. Id. at 1177 . See also the court's prior opinion in granting a preliminary injunction, 447 F. Supp. 243, 251-52 (W.D.N.Y. 1978).

161. These cases are discussed infra notes $224-40$ and accompanying text. Note that the focus in such cases is on whether a copyright owner is likely to have actual reasons for being willing to allow the use, or on whether he has manifested such a willingness; in such cases, the defendant "can justify himself upon some principle consistent with the entirety of ownership which the author has in his copyright." Reed v. Holliday, 19 F. 325, 327 (W.D.Pa. 1884). Likely consent reflects not just a measure of social welfare but also the fact that the copyright owner will not be injured. 
appear unwilling to deter such transfers by imposing the costs of obtaining actual consent. ${ }^{162}$

2. Externalities, Nonmonetizable Interest, and Noncommercial Activities. An analysis of the limitations of markets can also illuminate the special status that certain uses, such as scholarship, have in fair use tradition. The costs and benefits of the parties contracting for the uses often differ from the social costs and benefits at stake, so that transactions leading to an increase in social benefit may not occur. ${ }^{163}$ Thus, for example, a critic of the Warren Commission's investigation of the Kennedy assassination might write a "serious, thoughtful and impressive" 184 book that will further public interest more than the revenues of his book alone would indicate. One might say that publication of his book gives an "external benefit" to persons who might gain knowledge from the public debate sparked by the book without having purchased the book itself. Similarly, teaching and scholarship may yield significant "external benefits"; all of society benefits from having an educated citizenry and from advances in knowledge, yet teacher salaries and revenues from scholarly articles are arguably smaller than such benefit would warrant. When a defendant's works yield such "external benefits," the market cannot be relied upon as a mechanism for facilitating socially desirable transactions. ${ }^{165}$

162. Without fair use, the necessity of obtaining consent might wastefully apply even to those defendants whose activities would have been objected to by no one. The reason for this potential waste is that the availability of injunctive relief and statutory damages provides a motive for objecting, once a use has been made, even to those copyright owners who would have been inclined to consent ab ante. Once an injunction is obtained, the owner controls not merely the use of his own work, but also all aspects of defendant's work that are intertwined with it. Sec 17 U.S.C. § 502 (1976) (injunctions); id. § 503 (impounding and disposition of infringing articles). A great deal will then be at risk for the defendant, who might be willing to settle at high cost in order to lift the injunction and proceed with his enterprise. Also, the statutory damage provisions will ordinarily give a neglected copyright owner from $\$ 250$ to $\$ 10,000$, see id. $\$ 504$ (c), and there is a potential for costs and attorneys' fees. See id. § 505. Thus, even a copyright owner who would have been willing to consent to a use if his permission were sought before the use commenced might bring suit if the use had begun without that permission. Potential users would be unable to distinguish between those likely-consenting owners who would later object and those who would not. This possibility could in turn compel potential users to expend resources in negotiating for consent even from the willing. To award fair use where a typical copyright owner would be likely to consent breaks this circle.

Consider by analogy the hold-out problem that sometimes arises when a builder needs to purchase many individually owned tracts of land in order to accomplish a planned project. The problems caused by strategic hold-out behavior have been cited as justification for granting the government power to condemn property via eminent domain. See Calabresi \& Melamed, supra note 38 , at 1089. The injunctive and other modes of relief just discussed may give a copyright owner hold-out power over a defendant's work, and this may provide some justification for granting defendants the power to make use of the copyright owner's property via fair use. But see Demsetz, supra note 48, at 300 ("' $[S]$ o long as firms are free to compete for the trade of buyers, this [hold out] issue will reduce to a problem of wealth distribution and not to a problem of efficiency.").

163. See supra notes 32-87 and accompanying text.

164. See Time Inc. v. Bernard Geis Assocs., 293 F. Supp. 130 (S.D.N.Y. 1968).

165. For more thorough explanations of externalities, see, e.g., R. Posner, supra note 33, at 48-52; N. Singer, supra note 38, at 107-15; E. Mansfield, supra note 65, at 70-71, 74-75, 336-37. 
In cases of externalities, then, the potential user may wish to produce socially meritorious new works by using some of the copyright owner's material, yet be unable to purchase permission because the market structure prevents him from being able to capitalize on the benefits to be realized. Though such inability would not itself justify fair use, it may signal to the court that it should investigate whether the social costs of relying on the market are unacceptably high. It is therefore not surprising that section 107 of the Copyright Act, which addresses fair use, lists several uses that potentially exhibit positive externalities, such as "teaching," "scholarship," and "research," among the uses for which fair use may be given. ${ }^{166}$

Section 107 also directs the courts to consider "the purpose and character of the use, including whether the use is of a commercial nature or is for nonprofit educational purposes." 167 Where the defendant does not seek to earn profits, it may be argued that his willingness and ability to pay for the copyrighted resources he uses will not provide an accurate measure of the public interest served by his use. Distinctions between profit and nonprofit entities or commercial and noncommercial uses must, however, be employed with great caution. Henry Hansmann has suggested that nonprofit organizations can be fully participating members of the market process. ${ }^{168}$ Conversely, even commercial uses can face market failure. ${ }^{169}$

Distrust of the market may also be triggered when defendant's activities involve social values that are not easily monetized. When defendant's use contributes something of importance to public knowledge, political debate, ${ }^{170}$ or human health, ${ }^{171}$ it may be difficult to state the social worth of that contribution as a dollar figure. If the defendant's interest impinges on a first amendment interest, relying upon the market may become particularly inappropriate; constitutional values are rarely well paid in the marketplace and, while the citizenry would no doubt be willing to pay to avoid losing such values, it is awkward at best to try to put a "price" on them. ${ }^{172}$ Not surpris-

166. 17 U.S.C. § 107 (1976).

167. Id.

168. See Hansmann, The Role of Nonprofit Enterprise, 89 Yale L.J. 835 (1980).

169. See WXIA-TV v. Duncan, 8 Med. L. Rptr. 2075, 2078-79 (N.D. Ga. 1982) (need to maintain impartiality may preclude copyright owner from selling films of its news stories to subjects of such stories).

170. See, e.g., Keep Thomson Governor Comm. v. Citizens for Gallen Comm., 457 F. Supp. 957, 959-60 (D.N.H. 1978) (portion of political opponent's campaign music incorporated into political advertisement); Time, Inc. v. Bernard Geis Assocs., 293 F. Supp. 130, 146 (S.D.N.Y. 1968) (theory concerning Kennedy assassination). Note that in the latter case defendants had "offer[ed] to surrender to [the copyright owner] all profits of [the defendants] from the Book as royalty payment for a license to use the copyrighted Zapruder frames [of the Kennedy assassination], id. at 146, thereby further underlining the nonmonetizable nature of the concerns at stake.

171. Consider in this regard the solicitude shown by the Court of Claims for medicine and science in Williams \& Wilkins, discussed infra text accompanying notes 249-88.

172. Since a society may hold conflicting values, it may be incapable of weighing the importance of its various goals by any constant measure. See generally G. Calabresi \& P. Bobbit, supra note 34 . 
ingly, it has been suggested that fair use be granted when first amendment issues are involved. ${ }^{173}$

While in all of the cases described in this section-those involving external benefits, noncommercial uses, and nonmonetizable values-reason exists to distrust the market, it may be particularly difficult to determine whether the breakdown is substantial enough to frustrate the purposes for enforcing copyrights. What one deals with here may be not only traditional market failure, in the sense that conditions of perfect competiton have failed, but also a court's perception that the criterion of economic "value" is itself flawed. ${ }^{174}$ This concern is not illegitimate, but it should not be extended to make the copyright law an instrument of income redistribution. The courts should thus take care that they do not tax copyright owners to subsidize impecunious but meritorious users under the guise of maximizing value. ${ }^{175}$ Only when the public interest to be served is great, and the damage to the owner small, does the need for this caution diminish.

3. Anti-Dissemination Motives. Section 107 places first among the purposes for which fair use is appropriate "criticism" and "comment," uses that a copyright owner might be reluctant to license. ${ }^{176}$ Similarly, the treatment of burlesques and satires, which can be considered types of commentary, has been a volatile subject of fair use law. These uses share a type of market failure that helps to explain their fair use treatment and that is particularly important in a field where advancement of knowledge is the ultimate goal. The case law has tended to grant fair use treatment where copyright owners seemed to be using their property right not for economic gain but to control the flow of information.

The usual economic assumption is that the owner of a resource will either exploit that resource himself, or will sell it to someone else who will. The

173. Several commentators and courts have discussed the possibility that the first amendment may place a limitation on enforcement of the copyright owner's market rights or that fair use may embody some first amendment principles. See, e.g., Keep Thomson Governor Comm. v. Citizens for Gallen Comm., 457 F. Supp. 957, 959-60 (D.N.H. 1978); Denicola, supra note 39. Note that the copryight law itself provides that "[i]n no case does copyright protection extend to any idea," 17 U.S.C. $\S 102$ (b) (1976), a principle that operates regardless of injury to the copyright owner.

At least one district court has held that the first amendment could defeat an infringement suit. Triangle Publications, Inc. v. Knight-Ridder Newspapers, Inc., 445 F. Supp. 875 (S.D. Fla. 1978), aff'd on grounds of fair use without reaching first amendment issue, 626 F.2d 1171 (5th Cir. 1980). More common is the position that, while cases demanding the adoption of an express first amendment limitation on copyright may theoretically or eventually arise, "[c]onflicts between interests protected by the first amendment and the copyright laws thus far have been resolved by application of the fair use doctrine." Wainwright Securities, Inc. v. Wall Street Transcript Corp., 558 F.2d 91, 95 (2d Cir. 1977) (citations omitted), cert. denied, 434 U.S. 1014 (1978). See generally A. Latman \& R. Gorman, supra note 19, at 473-74 (discussing, inter alia, those cases that have rejected first amendment defenses).

174. See supra note 36 .

175. This may be the nature of Seltzer's concern when he warns the courts against engaging in reallocation of costs. See L. Seltzer, supra note 4 , at 38 .

176. 17 U.S.C. § 107 (1976). 
owner of a copyright, however, may not be willing to exploit all of the possible derivative works over which his copyright would ordinarily give him control. Even if money were offered, the owner of a play is unlikely to license a hostile review or a parody ${ }^{177}$ of his own drama; a publicity-shy tycoon who owns the copyright on magazine articles discussing his life is unlikely to license a biographer to use these articles; ${ }^{178}$ a candidate for governor is unlikely to license his copyrighted campaign music to be utilized in his opponent's televised advertisement; ${ }^{179}$ and the publisher of a periodical is unlikely to license his competitor to use his copyrighted magazine covers in comparative advertising. ${ }^{180}$ Because the owner's antidissemination motives make licensing unavailable in the consensual market, and because the free flow of information is at stake, a strong case for fair use can be advanced in these cases. ${ }^{181}$ Thus, it has often been suggested that burlesques and satires of copyrighted works deserve generous fair use treatment, since the copyright owners are unlikely to produce or license such work themselves. ${ }^{182}$

It might be argued that allowing fair use to criticisms, satires, and other materials that are potentially hostile to the copyrighted work will undermine incentives to produce original work. But while criticisms and the like may indeed reduce an owner's receipts, the goal of copyright is to generate incentives for the production of works that satisfy consumer tastes. If a criticism reveals a work's flaws, it is appropriate that demand for the work should decrease. ${ }^{183}$

177. "It has been held that an author is entitled to more extensive use of another's copyrighted work in creating a parody than in creating other fictional or dramatic works ...." Elsmere Music, Inc. v. NBC, 482 F. Supp. 741, 745 (S.D.N.Y. 1980), aff'd, 623 F.2d 252 (2d Cir. 1980) (citations omitted).

178. In Rosemont Enters., Inc. v. Random House, Inc., 366 F.2d 303, 311 (2d Cir. 1966), cert. denied, 385 U.S. 1009 (1967), Howard Hughes, having purchased through the Rosemont corporation the copyright on articles concerning his life, sought to restrain a biographer's use of the articles. "[I]t appears that the fair use defense was upheld in Rosemont at least in part because the court found that the plaintiff there was acting in bad faith seeking to prevent the publication of a legitimate biography of Howard Hughes." Meeropol v. Nizer, 560 F.2d 1061, 1069 (2d Cir. 1977) (footnote omitted), cert. denied, 434 U.S. 1013 (1978).

179. See Keep Thomson Governor Comm. v. Citizens for Gallen Comm., 457 F. Supp. 957 (D.N.H. 1978) (fair use granted to political opponent's use of copyrighted material).

180. In Triangle Publications, Inc. v. Knight-Ridder Newspapers, Inc., 626 F.2d 1171 (5th Cir. 1980), the publishers of the Miami Herald had shown old TV Guide covers as part of advertisements comparing TV Guide with the Herald's television supplement. TV Guide's motivation for refusing permission to use these covers would seem to be related not to a desire to exploit those covers' aesthetic qualities, but rather to a desire to prevent consumers from being persuaded by the ads. When TV Guide brought suit, fair use was found.

181. See cases and statute cited supra notes 176-80.

182. See, e.g., A. Latman \& R. Gorman, supra note 19, at 484-85; M. Nimmer, Comments and Views Submitted to the Copyright Office on Fair Use of Copyrighted Works, appended to Latman Study, supra note 102, at 42, 43. Sheldon Light valuably put this argument into an explicit economic framework. Light, Parody, Burlesque and the Economic Rationale for Copyright, 11 Conn. L. Rev. 615 (1979).

183. Of course, an injury to a copyright owner arising out of increased consumer knowledge would not be injury relevant to the second or third parts of the test. Copyright law seeks to guard against decreased demand for the copyright owner's product arising out of substitution; when decreased demand arises out of changed consumer preferences, that should be reflected in decreased revenues. See A. Latman \& R. Gorman, supra note 19, at 485 (raising a similar issue). 
Criticism is valuable, inter alia, because the market works to further the social good only when consumers have accurate information about the goods available. As the Supreme Court has written: "So long as we preserve a predominantly free enterprise economy, the allocation of our resources in large measure will be made through numerous private economic decisions. It is a matter of public interest that those decisions, in the aggregate, be . . well informed." ${ }^{184}$ A similar public policy argument would encourage the tastechanging functions of burlesque and satire. ${ }^{185}$ For these and other forms of criticism, fair use is particularly appropriate when the owner's reluctance to license use of his work is motivated by the desire to restrict the flow of information.

In discussing instances where copyright owners' antidissemination motives $^{186}$ trigger a distrust of the market, however, it must be stressed that refusals to grant permission to license should ordinarily be honored. A refusal to license must not automatically justify a right to fair use; markets can function only if owners have a right to say "no" as well as "yes." 187 When an owner refuses to license because he is concerned that defendant's work will substitute for his own work or derivative works, ${ }^{188}$ the owner is representing not only his own interest, but also the interest of his potential customers and thus the public interest. ${ }^{189}$ Market failure should be found only when the defendant can prove ${ }^{190}$ that the copyright owner would refuse to license out of a desire unrelated to the goals of copyright-notably, a desire to keep certain information from the public. ${ }^{191}$ Unfortunately, some courts seem to have viewed even some legitimate refusals as justifying fair use treatment. ${ }^{102} \mathrm{~A}$

184. Virginia Pharmacy Bd. v. Virginia Consumer Council, Inc., 425 U.S 748, 765 (1976).

185. Economics seeks to satisfy consumer tastes, however they may evolve, and assumes "that man is a rational maximizer of his ends in life." R. Posner, supra note 33, at 3.

186. Such motives might in an extreme case be termed "bad faith," reflecting on the equitable origins of the fair use doctrine. See Meeropol v. Nizer, 560 F.2d 1061, 1069 (2d Cir. 1977), cert. denied, 434 U.S. 1013 (1978).

187. See Roy Export Co. Estab. of Vaduz v. CBS, 503 F. Supp. 1137, 1147 n.6 (S.D.N.Y. 1980), aff'd, 672 F.2d 1095 (2d Cir. 1982).

188. See Metro-Goldwyn-Mayer, Inc. v. Showcase Atlanta Coop. Prods., Inc., 479 F. Supp. 351, 360-61 (N.D. Ga. 1979) ("The Court first recognizes that a non-parodic or non-satiric stage version of [plaintiff's work] Gone With the Wind is a protected derivative use of the original works which only the holders of the valid, existing copyrights in such works have a right to exploit. . . . [Defendant's play] 'Scarlett Fever' could harm a potential market for or value of a stage version of Gone With the Wind.").

189. But see Goldstein, supra note 39, at 1056 ("The infringer is . . the sole proponent of the generalized interest in access .....").

190. On the allocation of the burden of proof, see supra text accompanying notes 135-148.

191. It should also be noted, however, that while fair use may be appropriate when copyrights in published works are improperly used for the purpose of manipulating public debate, fair use should not be used to force disclosure of works that the author has heretofore kept secret. The right to privacy that found expression in the "right of first publication" in common-law copyright, see Warren \& Brandeis, supra note 70 , should still be honored, at least for truly private works such as undisclosed diaries and the like. See Senate Report, supra note 26, at 64 ("The applicability of the fair use doctrine to unpublished works is narrowly limited . . .."). But see M. Nimmer, supra note $97, \S 13.05$ n.2, at $13-54$.

192. In New York Times Co. v. Roxbury Data Interface, Inc., 434 F. Supp. 217 (D.N.J. 1977), the court refused, on fair use grounds, to enjoin defendants from producing an index that 
clearer focus on whether the nature of the reluctance to license involved market failure could help avoid this problem.

Even though the presence of antidissemination motives signals a reason to mistrust the market, a market breakdown is not always the result. Where, for example, a potential satirist plans a remunerative commercial use whose popularity will depend in part on the attractive or dramatic qualities of the original being satirized, he may be willing to offer a substantial payment for the right to use elements of the copyrighted work in a satirical form. The copyright owner might accept such payment in the expectation that it should more than compensate him for any loss he might experience in his primary market as a result of the satirical treatment. If a market bargain would be possible, fair use should be denied ${ }^{193}$ unless the court perceives a danger that the owner might use his market right to distort the satiric content.

Several factors already employed by the courts and Congress are relevant to the inquiry into whether a bargain for a use could take place. As mentioned, the commercial nature of the use is important, ${ }^{194}$ as is substantiality. ${ }^{195}$ The more commercial the nature of the use, and the more the defendant's work will compete with the copyrighted work, the greater the impact of any given quantity of copying is likely to be. ${ }^{196}$ Also, anticipated profit-the incentive for a market bargain-is more likely to be high where the taking is extensive. These criteria in turn can have an impact upon the court's assessment of substantiality. ${ }^{197}$ If despite the theoretical possibility of an antidissemination motive the court feels that a market bargain could have been reached, or that the defendant is operating in a realm that the copyright owner himself might have been willing to exploit, ${ }^{198}$ fair use should be denied.

the copyright owners had declined to publish. The court was influenced by the plaintiff's unwillingness to publish a work like that produced by defendants, even though the plaintiff's unwillingness may have stemmed from a desire to protect its own derivative works. Cf. Roy Export Co. Estab. of Vaduz v. CBS, 503 F. Supp. 1137, 1146 n.5 (S.D.N.Y. 1980), ("[I]f the Roxbury court did consider harm to the potential market of derivative work to be irrelevant to a determination of the availability of the fair use defense, . . we disagree . . ."'), aff'd, 672 F.2d 1095 (2d Cir. 1982). Similarly, in Time, Inc. v. Bernard Geis Assocs., 293 F. Supp. 130 (S.D.N.Y. 1968), the owner of copyright in the Zapruder photographs of the Kennedy assassination denied permission to use the pictures. The denial did not come out of any antidissemination motive (e.g., to restrain criticism of the Warren Commission), but rather out of a desire to exploit the photographs economically. While there may have been some impropriety in plaintiff's plans for "monopolizing" the films, see Goldstein, supra note 39, at 986-88, 1035-55, it is preferable to view the market failure in Geis as not involving an antidissemination motive. The case is better viewed as involving an externality or nonmonetizable interest. See infra text accompanying notes 163-75.

193. This is what appeared to occur in the Benny case. See infra notes $221 \& 223$.

194. See 17 U.S.C. § 107(1) (Supp. IV 1980).

195. See id. § 107(3).

196. See id. § 107(4).

197. See Loew's, Inc. v. CBS, 131 F. Supp. 165, 184-85 (S.D. Cal. 1955), aff'd sub. nom. Benny v. Loew's, Inc. 239 F.2d 532 (9th Cir. 1956), aff'd per curiam by an equally divided Court sub nom. CBS v. Loew's, Inc., 356 U.S. 43 (1958).

198. See also WXIA-TV v. Duncan, 8 Med. L. Rptr. 2075, 2079 n.9 (N.D. Ga. 1982) (issue of whether "plaintiff[] [television station's] copyright market inherently excludes" use in question held relevant to market impact factor of fair use). 


\section{B. Assessment of Injury and Benefit}

The courts generally speak of "balancing" or "weighing" in the fair use area without employing any coherent methodology for determining how the various factors thrown into the pot-such as public interest and injury to the copyright owner-should be addressed. ${ }^{109}$ The fair use test presented here can clarify that process by suggesting, first, that "public interest" cannot provide a justification for fair use unless there is a reason to believe that the market cannot be relied upon to serve that interest; and second, that where the market cannot be relied upon, market measures for comparing an owner's loss with a user's gain can provide some objective guide to determining where the public interest lies. Since the courts' amorphous handling of injury and benefit already reveals patterns that are consistent with the fair use test advanced here, the test in turn may serve to clarify the existing case law. It is therefore worthwhile to explore further some aspects of how the second part of the instant fair use test finds expression in the cases.

1. Defendant's Interest. The fair use test presented here requires that in order to warrant consideration for fair use protection the defendant's use must have some positive social value. ${ }^{200}$ The cases do indicate that fair use will be denied where the court perceives the defendant's use to be without value, as where the defendant is using the copyrighted work for the purpose of achieving a deception, e.g., falsely to indicate that the author of the copyrighted

199. Often the balancing concept employed in the cases is more diffuse than that applied in the second part of the fair use test set forth here. This Second Circuit statement is fairly typical: "The fair use doctrine offers a means of balancing the exclusive rights of a copyright holder with the public's interest in dissemination of information affecting areas of universal concern, such as art, science and industry." Wainwright Securities Inc. v. Wall Street Transcript Corp., 558 F.2d 91, 94 (2d Cir. 1977). For examples of the courts' assessments of injury and benefit see Meeropol v. Nizer, 560 F.2d 1061 (2d Cir. 1977), cert. denied, 434 U.S. 1013 (1978); Rosemont Enters., Inc. v. Random House, Inc., 366 F.2d 303 (2d Cir. 1966), cert. denied, 385 U.S. 1009 (1967).

Some cases do directly weigh the copyright owner's loss against the public benefit, but even there it is unclear at what stage weighing becomes relevant. See, e.g., Time, Inc. v. Bernard Geis Assocs., 293 F. Supp. 130 (S.D.N.Y. 1968), discussed supra note 192.

200. Only the social value of those parts of defendant's work that need to use plaintiff's work is relevant here. It is necessary to evaluate not just the value of defendant's work, but also whether he needed to use plaintiff's work to achieve that value. See Roy Export Co. Estab. of Vaduz v. CBS, 503 F. Supp. 1137, 1144 (S.D.N.Y. 1980) (in assessing the purpose and character of defendant CBS's use, "[t] he jury could reasonably have concluded that if . . . it was essential to proper coverage of [Charlie] Chaplin's death that some film clips be shown, the showing of excerpts from films in the public domain would have been sufficient, and that CBS's decision to broadcast the offending version was motivated by commercial rather than educational considerations"), aff'd, 672 F.2d 1095, 1100 (2d Cir. 1982) (assessing defendant's claim of a first amendment privilege in the copyright field) ("The showing of copyrighted [Chaplin] films was not essential to CBS's news report of Charlie Chaplin's death or to its assessment of his place in history; public domain films were available for the purpose, and the public is already generally familiar with his work."). See also Walt Disney Prods. v. Air Pirates, 581 F.2d 751, 756-59 (9th Cir. 1978) (evaluation of "necessity" in parody situations), cert. denied, 493 U.S. 1132 (1979); Meeropol v. Nizer, 560 F.2d 1061, 1071 n.14 (2d Cir. 1977) ("'necessity for verbatim copying"), cert. denied, 434 U.S. 1013 (1978). See also Denicola, supra note 39, at 306-13 (necessity in the first amendment context). 
work has endorsed the user's product. ${ }^{201}$ If, on the other hand, the use has value, the courts will consider its nature and measure its importance. ${ }^{202}$

It may seem inconsistent that courts are willing to evaluate the public interest or worthiness of defendant's work in the fair use context, yet are unwilling, when granting protection in the first instance, to investigate whether plaintiff's work is "worthy" of copyright or, in the constitutional phrase, likely to "Promote the Progress of Science." ${ }^{203}$ But, in light of the comparatively limited application of fair use doctrine, the distinction is defensible. If authors were required to prove the intellectual or aesthetic virtues of their works in order to obtain copyright protection, the courts would be continually embroiled in hard questions about artistic and other measures of quality for which they are ill-equipped and for which the marketplace criterion of consumer demand might be a more appropriate measure. ${ }^{204}$ By contrast, the fair use inquiry into how greatly defendant's work serves the public interest, and how significantly that interest would be impaired if infringement were found, needs to be considered only if market failure has been proven. ${ }^{205}$ Furthermore, the presence of market failure in fair use cases suggests that consumer demand will not be appropriately reflected in owner/user transactions, so that the court may be the only institution capable of making the judgment. In addition, the case-by-case flexiblity of fair use allows the courts to weigh the value criterion in defendant's favor only when they do feel equipped to make such judgments. This judicial diffidence may explain why fair use is often found in certain recurring categories, ${ }^{206}$ or in other instances where the public interest is quite obvious. ${ }^{207}$

201. In Martin Luther King, Jr. Center for Social Change, Inc. v. American Heritage Prods., 508 F. Supp. 854 (N.D. Ga. 1981), defendant corporation had marketed plastic busts of Dr. King, using the name of the Center for Social Change and using excerpts from Dr. King's copyrighted speeches in its advertisements and other materials. In rejecting the defendant's claim of fair use, the court noted that there was no "public interest consideration ... present in this case. . . . Defendants' use of substantial passages from Dr. King's creative works was purely to induce consumers to buy the plastic busts and to convey the [false] impression that the Center approved of the product. This is not a 'fair use.' " Id. at 861 . See also Amana Refrigeration, Inc. v. Consumers Union of the United States, Inc., 431 F. Supp. 324, 326 (N.D Iowa 1977) (deceptive use of quotations), discussed supra note 141 .

This consideration may also help to explain the court's decision in Walt Disney Prods. v. Air Pirates, 581 F.2d 751 (9th Cir. 1978), cert. denied, 493 U.S. 1132 (1979), for the value of the defendants' depiction of "counter-cultural" lifestyle's may have been difficult for the court to perceive. This illustrates one danger of relying on a court's subjective measures of value.

202. See generally A. Latman \& R. Gorman, supra note 19, at 473-75 (suggesting that a " 'public interest' factor outweighing all others" may be developing that is "arguably bubbling under the surface of cases involving new technology"').

203. See Bleistein v. Donaldson Lithographing Co., 188 U.S. 239 (1903). In Bleistein, Justice Holmes wrote: "It would be a dangerous undertaking for persons trained only to the law to constitute themselves final judges of the worth of pictorial illustrations, outside of the narrowest and most obvious limits." Id. at 251. See also Light, supra note 182, at 635-36 (a test for fair use should not allow a court to make literary evaluations of parodies and satires).

204. See Bleistein v. Donaldson Lithographing Co., 188 U.S. 239, 251-52 (1903).

205. See supra text accompanying notes $89-92$.

206.

Whether the privilege [of fair use] may justifiably be applied to particular materials turns initially on the nature of the materials, e.g., whether their distribution would serve 
One unresolved question is whether defendant's work serves the public interest if it is primarily entertainment. ${ }^{208}$ Some courts have suggested that entertainment has a social value, ${ }^{209}$ while a recent opinion demanded that defendant show some additional claim to serving the public. ${ }^{210}$ An economic

the public interest in the free dissemination of information and whether their preparation requires some use of prior materials dealing with the same subject matter. Consequently, the privilege has been applied to works in the fields of science, law, medicine, history and biography.

Rosemont Enters., Inc. v. Random House, Inc., 366 F.2d 303, 307 (2d Cir. 1966) (citation omitted), cert. denied, 385 U.S. 1009 (1967).

207. See, e.g., Time, Inc. v. Bernard Geis Assocs., 293 F. Supp. 130, 146 (S.D.N.Y. 1968) ("There is a public interest in having the fullest information available on the murder of President Kennedy. [Defendant] Thompson did serious work on the subject and has a theory entitled to public consideration."). See also supra notes 170-73 and accompanying text.

208. It can be argued that entertainment has a social value as worthy of protection pro tanto as any other-which is the position taken by this Article-or that entertainment uses have no value entitled to fair use protection, see infra note 210 , or that its value is not susceptible to judicial appraisal, Universal City Studios, Inc. v. Sony Corp. of America, 480 F. Supp. 429, 452 (C.D. Cal. 1979) (refusing to disqualify copyrighted "New Mickey Mouse Club" episodes from fair use treatment despite an unwillingness to evaluate their social merit), rev'd in part and remanded, 659 F.2d 963 (9th Cir. 1981), cert. granted, 102 S.Ct. 2926 (1982). Cf. Stanley v. Georgia, 394 U.S. 557, 566 (1969) (for first amendment purposes, "[t]he line between the transmission of ideas and mere entertainment is much too elusive for this Court to draw, if indeed such a line can be drawn at all').

209. Thus, the Second Circuit has seen social value in humor. See Elsemere Music, Inc. v. NBC, 623 F.2d 252, 253 \& n.1 (2d Cir. 1980) (per curiam) (emphasis added):

[I]n today's world of often unrelieved solemnity, copyright law should be hospitable to the humor of parody . . . . A parody is entitled at least to 'conjure up' the original. Even more extensive use would still be fair use, provided the parody builds upon the original, using the original as a known element of modern culture and contributing something new for humorous effect or commentary.

In the Betamax case, the Court of Appeals for the Ninth Circuit refused to base its holding of no fair use on the mere fact that the challenged uses served entertainment purposes. Although the Ninth Circuit noted that "there seems to be some indication that the scope of fair use is greater when informational type works, as opposed to more creative products, are involved," and that "[i]f a work is more appropriately characterized as entertainment, it is less likely that a claim of fair use will be accepted," Universal City Studios, Inc. v. Sony Corp. of America, 659 F.2d 963, 972 (9th Cir. 1981) (footnote omitted), cert. granted, 102 S.Ct. 2926 (1982) (No. 81-1687), the court's opinion did consider the entertainment to be of some value and took that value into account pro tanto in making its fair use determination. Id. at 971.

210. In Metro-Goldwyn-Mayer Inc. v. Showcase Atlanta Coop. Prods., Inc., 479 F. Supp. 351 (N.D. Ga. 1979), the owners and creators of "Scarlett Fever," a musical play based on Gone With The Wind, argued that their use of the copyrighted material was a parody or satire protected by fair use. The court rejected this contention, reasoning, inter alia, that

in order to constitute the type of parody eligible for fair use protection, parody must do more than merely achieve comic effect. It must also make some critical comment or statement about the original work which reflects the original perspective of the parodist-thereby giving the parody social value beyond its entertainment function.

Id. at 357 (footnote omitted).

The court in Metro-Goldwyn-Mayer took this position because it believed that "[o]therwise, any comic use of an existing work would be protected" from liability via the fair use doctrine. Id. However, recognizing that entertainment has social value would not entitle all comic works to immunity from liability, as the court supposed; under a market-oriented approach, fair use would not be available unless there were justification for departing from the market. Without that market failure, no amount of social value should justify free use. See supra notes $89-91$ and accompanying text.

It is true that a lack of critical comment or perspective should militate against fair use, but the reason is not that such work lacks all social value. Rather, if an alleged "parody" fails to give 
analysis would consider entertainment to be valuable, for it is an object of consumer preference like any other. ${ }^{211}$ However, it is likely that an entertainment use will be able to pay its own way through the market, ${ }^{212}$ so that market failure will less often appear in those contexts. ${ }^{213} \mathrm{~A}$ commercial use like entertainment is also likely to cause more injury than a noncommercial one. ${ }^{214}$ Thus, while entertainment uses, like commercial uses, may serve the public welfare, ${ }^{215}$ where they are present the fair use test is unlikely to be satisfied for other reasons.

2. Plaintiff's Interest. Injury to the plaintiff's market has long been considered the dominant factor in fair use adjudication. ${ }^{216}$ Injury most strikingly results when a defendant advertises his work as a possible substitute for the copyrighted original. ${ }^{217}$ When a defendant uses plaintiff's copyrighted

audiences a new opinion of the copyrighted work, fair use may be barred because there is no market failure, i.e., because there is nothing to indicate that the copyright holder would have refused to license this use of his work. See supra notes 89-91 and accompanying text. In sum, the holding of the Metro-Goldwyn-Mayer court can be squared with the view advanced by this Article, that entertainment is a valuable use entitled pro tanto to fair use protection, if it is recognized that the court was using the language of social value to address whether a market failure appeared. Such an interpretation of Metro-Goldwyn-Mayer fits the facts of the case: there was no suggestion that the holders of copyright interests in Gone With The Wind objected to defendant's production in order to prevent criticism of the famous work from reaching the public or had any other antidissemination motive. Rather, the inference was that plaintiffs were acting to protect their rights to license similar derivative works of their own. See $479 \mathrm{~F}$. Supp. at 360-61. Since no market failure appeared, fair use was appropriately denied.

211. Some courts appear to award entertainment a social value, but weigh it less heavily in the fair use balance than other uses. The Ninth Circuit Court of Appeals arguably took this position in the Betamax case, finding home television recording to be of some value but of less importance than the "serious damage to medical science" that concerned the Williams \& Wilkins court. Universal City Studios, Inc. v. Sony Corp. of America, 659 F.2d 963, 972 (9th Cir. 1981), cert. granted, 102 S.Ct. 2926 (1982) (No. 81-1687).

212. Entertainment is more likely to be able to recapture its social value in receipts than are the typical objects of fair use solicitude such as scholarship, and the monetary marketplace measures are likely to be more suitable gauges of the value of entertainment. See supra text accompanying notes 163-75. The courts often conflate the issues of whether a use encounters market failure and whether it has social value. See, e.g., Martin Luther King, Jr. Center for Social Change, Inc. v. American Heritage Prods., Inc., 508 F. Supp. 854, 861 (N.D. Ga. 1981) ("Although the fact that a use of a work is for commercial gain will not automatically preclude a finding of 'fair use,' generally fair use will be more readily recognized where the defendant's use is for educational, historical, or scientific purposes.").

213. To satisfy the first element of the fair use test presented herein, market failure must be shown. See supra notes $89-91$ and accompanying text.

214. The presence of injury makes it more difficult to satisfy the second and third elements of the fair use test presented herein. See supra notes 92-103 \& 104-124 and accompanying text.

215. "Whether an author or publisher reaps economic benefits from the sale of a biographical work ... has no bearing on whether a public benefit may be derived from such a work." Rosemont Enterprises, Inc. v. Random House, Inc., 366 F.2d 303, 307 (2d Cir. 1966), cert. denied, 385 U.S. 1009 (1967).

216. See M. Nimmer, supra note $97, \S 13.05$ [A][4], at 13-64 to 13-65; Triangle Publications v. Knight-Ridder Newspapers, Inc., 626 F.2d 1171, 1177 (5th Cir. 1980).

217. See, e.g., Wainwright Secs. Inc. v. Wall Street Transcript Corp., 558 F.2d 91, 93-94, 96 (2d Cir. 1977) (enjoining weekly newspaper that had regularly abstracted plaintiff's copyrighted research reports, and had advertised the availability of such abstracts as one of its strong selling points), cert. denied, 434 U.S. 1014 (1978); Meeropol v. Nizer, 560 F.2d 1061, 1069-71 (2d Cir. 1977) (reversing summary judgment for defendants who used plaintiff's copyrighted letters without permission in book about plaintiff's parents), cert. denied, 434 U.S. 1013 (1978). The 
work in a way that competes with that work, fair use is particularly unlikely. ${ }^{218}$ Where the defendant's work reaches a market that the plaintiff has not yet tapped, however, the injury is less apparent and the case treatment has been disparate. ${ }^{219}$ The analysis presented here suggests that probable injury to those derivative work markets that plaintiff might exploit is relevant to determining whether or not a use is fair. ${ }^{220}$ The defendant himself may be one of the plaintiff's potential customers, ${ }^{221}$ and computation of injury should in-

court in Meeropol noted that "[a]lthough these letters represent less than one percent of [defendant's book], the letters were prominently featured in promotional material for the book," 560 F.2d at 1071 (footnote omitted), and "whether the book is bought because it contains the Rosenberg letters" may be considered, id. at 1071 n.14. See also Time, Inc. v. Bernard Geis Assocs., 293 F. Supp. 130 (S.D.N.Y. 1968) (plaintiff's motion for summary judgment denied on grounds of fair use where defendant author used sketches of copyrighted Zapruder films of Kennedy assassination as part of book criticizing the Warren Commission). The court in Geis considered the question of audience motivation quite relevant. In an opinion granting fair use treatment, the court found that " $[t]$ he Book is not bought because it contained the Zapruder pictures ." 293 F. Supp. at 146.

218. The more that is taken from the copyrighted work, the more likely is defendant's work to substitute for the original, so that the amount of the taking is relevant to injury. One of the fair use factors listed in the statute is "the amount and substantiality of the portion used in relation to the copyrighted work as a whole." 17 U.S.C. § 107(3) (Supp. IV 1980). In the Betamax case compare the Ninth Circuit's view of the substantiality criterion, Universal City Studios., Inc. v. Sony Corp. of America, 659 F.2d 963, 973 (9th Cir. 1981) ("“excessive copying precludes fair use" "; lack of market injury is " 'immaterial" ) (relying, inter alia, on the Benny case, see infra note 221), cert. granted, 102 S. Ct. 2926 (1982) (No. 81-1687) with that of the district court, $480 \mathrm{~F}$. Supp. 429, 454-56 (C.D. Cal. 1979) ("the substantiality factor is inextricably bound with the issue of harm"). The substantiality criterion is also relevant to market failure analysis, for with less substantial takings the impact of transaction costs on the market is likely to be greater and the amount of injury is likely to be less. See supra notes 31 (fair use factors) \& 155-59 (transaction costs) and accompanying text.

219. Compare New York Times v. Roxbury Data Interface, Inc., 434 F. Supp. 217 (D.N.J. 1977) (harm to plaintiff from loss of potential derivative market for Times index insufficient to bar defendant's production of index) with Roy Export Co. Estab. of Vaduz v. CBS, 503 F. Supp. 1137 (S.D.N.Y. 1980) (harm to derivative market for Chaplin film biographies, which plaintiff had already entered, argues against fair use treatment), aff'd, 672 F.2d 1095 (2d Cir. 1982), both discussed supra note 192.

220. This is also the view taken by the court in Roy Export Co. Estab. of Vaduz v. CBS, 503 F. Supp. 1137, 1145-46 \& n.5 (S.D.N.Y. 1980), aff'd, 672 F.2d 1095 (2d Cir. 1982). See also Metro-Goldwyn-Mayer v. Showcase Atlanta Coop. Prods., Inc., 479 F. Supp. 351, 360-61 (N.D. Ga. 1979) (discussed supra note 188). As indicated by WXIA-TV v. Duncan, P. Med. L. Reptr. 2075, 2078-80 (N.D. Ga. 1982), a court should factually determine whether plaintiff does exploit or could exploit the market tapped by defendant. Antidissemination motives (e.g., the satire cases) or conflicts of interest (e.g., the WXIA case) may remove a use from potential exploitation by the copyright owner.

221. A focus on this often neglected fact may clarify one source of persistent confusion in this area: the extent to which a finding of "no injury" should itself justify fair use.

In the famous Benny case, Loew's, Inc. v. CBS, 131 F. Supp. 165 (S.D. Cal. 1955), aff'd sub nom. Benny v. Loew's, Inc., 239 F.2d 532 (9th Cir. 1956), aff'd per curiam by an equally divided Court sub nom. CBS v. Loew's, Inc., 356 U.S. 43 (1958), Jack Benny produced a fifteen-minute television skit that burlesqued the movie "Gaslight." He borrowed the movie's characters, plot development, setting, and even an appreciable amount of its dialogue. The district court held that the burlesque was an infringement, stating, inter alia, that

[t] he mere absence of competition or injurious effect upon the copyrighted work will not make a use fair. The right of a copyright proprietor to exclude others is absolute and if it has been violated the fact that the infringement will not affect the sale or exploitation of the work or pecuniarily damage him is immaterial.

Id. at 184 (emphasis added). However, the Benny court discussed only the effect of defendant's 
clude the amount that the defendant would have paid for the work had he not bypassed the market. If defendant utilizes the copyrighted work for sale in a new market, those receipts provide some guide to what defendant might have paid. ${ }^{222}$ Similarly, if the defendant realizes a cost savings in using plaintiff's work as a building block for his project, the cost saved ${ }^{223}$ may provide some guide to what defendant would have paid and therefore to what plaintiff has lost.

3. Balancing Under Consent Analysis. The role of consent has been the subject of some discussion in traditional fair use commentary. ${ }^{24}$ Several cases have found the copyright owner's apparent consent to favor a fair use holding, ${ }^{225}$ or have indicated that a custom of permitted use (i.e., a pattern of apparent consent among copyright owners) could favor fair use. ${ }^{226}$ The important study that Professor Latman prepared for the Senate Committee on the Judiciary presented the consent of the reasonable copyright owner as a potential unifying principle, ${ }^{227}$ but other commentary has dismissed consent analyses as "fictional." 228

use on plaintiff's "sale or exploitation" to customers other than defendant himself, a factor that we might call "competitive injury." There is another potential type of injury: the loss of what defendant himself might pay to use plaintiff's work in his own projects, which we might call "building block injury." The mere absence of competitive injury should not justify fair use, not only because of the market failure requirement, but also because sufficient building block injury may be present to cause substantial injury to incentives. Building block injury will be absent only with complete market failure between copyright owner and user.

After Benny lost the case, "trade rumour" reported that the copyright owners licensed Benny to use the material for $\$ 100,000$. Netterville, Copyright and Tort Aspects of Parody, Mimicry and Humorous Commentary, 35 S. Cal. L. Rev. 225, 233 (1962). This suggests both that despite the burlesque form of the use, see supra text accompanying notes 193-98, there was no market failure, and that the "building block" receipts were substantial. See infra note 223 . Infringement rather than fair use was the proper result. The court's language suggesting there was "no injury" is thus somewhat deceptive.

222. This calculation is consistent with the successful copyright plaintiff's ability to recover profits as well as damages to the extent they do not overlap. See 17 U.S.C. § 504(b) (1976).

223. See, e.g., Northwestern Bell Tel. Co. v. Bedco of Minn., Inc., 501 F. Supp. 299, 300 (D. Minn. 1980) (defendant soliciting advertising and listings for new yellow pages directory sent prospective advertisers photocopies of such businesses' listings in the copyrighted Northwestern Bell yellow pages; preliminary injunction granted). The court in Northwestern Bell noted: "[W] hat a subsequent compiler cannot do is copy from an' already copyrighted directory and save himself the labor and expense incurred by the prior compiler." Id. at 302 (quoting Southwestern Bell Tel. Co. v. Nationwide Indep. Directory Serv., Inc., 371 F. Supp. 900, 906 (W.D. Ark. 1974)).

In two leading companion cases, a television parody of the movie "Gaslight" that used most of that movie's plot elements was held an infringement, while fair use was granted to a parody of "From Here to Eternity" that depended less on the movie's own plot lines for interest. Compare Loew's, Inc. v. CBS, 131 F. Supp. 165, 170-71 n.9 (S.D. Cal. 1955), aff'd sub nom. Benny v. Loew's, Inc., 239 F.2d 532 (9th Cir. 1956), aff'd per curiam by an equally divided Court, 356 U.S. 43 (1958) ("Gaslight"), with Columbia Pictures Corp. v. NBC, 137 F. Supp. 348, 350-58 (S.D. Cal. 1955) ("From Here to Eternity"). As mentioned supra note 221, the infringers of "Gaslight" must have considered the substantial building blocks borrowed from the movie to be of value; they reportedly purchased a license, after loss of the case, at a price of $\$ 100,000$.

224. See, e.g., Cohen, supra note 146, at $45,50-51$.

225. See infra notes $230-33$ and accompanying text.

226. See Cohen, supra note 146 at $43,51-52$, and sources cited therein; infra note 235 .

227. Professor Latman suggested:

[T] he tests [for fair use] may perhaps be summarized by: importance of the material 
Economic analysis helps to explain why apparent consent and custom may weigh in favor of fair use and also helps to delineate the limits of their applicability. As intimated earlier, hypothetical consent may serve as a useful model for balancing the injuries and benefits of a given copyright use. Cases in which courts have employed consent terminology provide implicit examples of such balancing and illustrate related economic principles. ${ }^{220}$

A court is likely to find fair use when a copyright owner's behavior gave apparent consent to the use, even if that copyright owner never actually intended to allow the specific use in question. ${ }^{230}$ In such cases, consent is inferred from the plaintiff's actions; this inference is consistent with society's need to make its members responsible for their actions. ${ }^{231}$ Since it is less expensive for persons who own copyrights to avoid misleading potential users than it is for users to seek explicit permission from all owners whose behavior has implied permission to use, ${ }^{232}$ a fair use holding in this context stimulates more economically desirable behavior than would a finding of liability. ${ }^{233}$

copied or performed from the point of view of the reasonable copyright owner. In other words, would the reasonable copyright owner have consented to the use? At times, custom or public policy defines what is reasonable.

Latman Study, supra note 102, at 15.

228. See, e.g., M. Nimmer, supra note 97 , § 13.05, at 13-55 (1980).

229. This section discusses several types of consent. Apparent consent asks whether an individual copyright owner seems to have given his actual consent. "Likely" or "probable" consent (custom) asks whether an individual copyright owner, if asked, would give his consent. Hypothetical consent under the second branch of the fair use test asks if a copyright owner who was offered a perfect market price would consent. Each type of consent provides a mode of structuring the inquiry into whether social welfare is served by a transaction, so each is relevant to the second branch of the fair use test. In addition, facts that suggest the presence of apparent and likely consent indicate that little would be gained by insistance on a market bargain, so that they are relevant to the first part of the fair use test and, because consent indicates there is no injury to the owner, to the third part of the test as well. Apparent and likely consent thus serve as illustrations unifying the three parts of the test.

230. See Karll v. Curtis Publishing Co., 39 F. Supp. 836 (E.D. Wis. 1941) (eight lines of a song written by a fan of the Green Bay Packers quoted in magazine articles about the team; songwriter's complaint against the magazine dismissed on grounds of fair use). The court stated, inter alia: "When the plaintiff dedicated the song to the Green Bay Packers, by implication at least he consented to a reasonable use thereof associated with the Packers." Id. at 837. See also American Inst. of Architects v. Fenichel, 41 F. Supp. 146 (S.D.N.Y. 1941) (publisher of booklet of forms sued defendant who made 6 copies of one form apparently for use in architectural business; cover of the booklet stated: "The Institute's forms [are] intended for use in actual practice ... and ... may be drawn upon by architects in improving their own forms ..." "; summary judgment awarded to defendant on grounds of fair use). Note that in both Karll and Fenichel, apparent consent was only one of several factors relied upon.

231. As Dean Prosser has written:

Consent to an act is simply willingness that it shall occur. Actual willingness ... . will prevent liability . . . even though the plaintiff has done nothing to manifest it to the defendant. But the converse is also true, that a manifestation of consent, upon which the defendant may reasonably rely, will be equally effective even though there is no willingness in fact. In our society we must perforce rely upon the overt words and acts of others, rather than upon their undisclosed minds .... .

W. Prosser, supra note 99, at 101 (footnotes omitted).

232. Most such owners will probably have intentions consistent with their actions, and seeking consent of the already-willing is wasteful.

233. A fair use holding here also respects the reliance interests that equity concepts of fairness have long recognized. The goal of providing incentives to encourage economically 
Although apparent consent may provide an acceptable basis for fair use, its absence should not trigger liability. Instead, the absence of apparent consent should merely make the court examine whether other justifications for market bypass may be present. Thus, posting an explicit "do not copy" warning on a book may negate a copyright owner's apparent consent. The "do not copy" warning would not, however, prevent a court from granting fair use of that work on grounds other than apparent consent, so that the courts' freedom to grant fair use despite such a warning does not render "fictional" the use of a consent rationale in appropriate cases.

Just as judicial reluctance to stimulate needlessly expensive behavior may be at the core of the apparent consent cases, so too it may explain those cases in which the courts exhibit a sensitivity to whether a challenged use is minor, ${ }^{234}$ or customary. ${ }^{235}$ Similarly, in instances where defendant's use is likely to yield the owner himself a net benefit, ${ }^{236}$ such complements ${ }^{237}$ are likely to

desirable behavior is relevant to the legal import of reliance in contexts other than fair use as well. See, e.g., Posner, supra note 33, at 67-70 (reliance in the contract context).

234. Among the fair use factors listed in $\S 107$ are "the amount and substantiality of the portion used in relation to the copyrighted work as a whole," and "the effect of the use upon the potential market for or value of the copyrighted work." 17 U.S.C. § 107 (3) \& (4) (1976). The smaller the amount taken and the smaller the economic impact, the more likely consent would appear to be.

235. Fair use has sometimes been described as that which is "reasonable and customary." Note, 15 S. Cal. L. Rev. 249, 250 (1942); Latman Study, supra note 102, at 7. See also Shapiro, Bernstein \& Co. v. P.F. Collier \& Son Co., 26 U.S.P.Q. (BNA) 40, 42 (S.D.N.Y. 1934); MacMillan Co. v. King, 223 F. 862 (D. Mass. 1914).

It is likely that the mass of fair use situations go unlitigated because owners willingly tolerate customary uses. A newspaper review that summarizes the plot of a reviewed play provides one classic example. Though widely presumed to be fair use, it is not a focus of much litigation itself. Presumably playwrights do consent to this use. Similarly, most scholars actively want their ideas to become part of the dialogue in their fields, even though participation in such dialogue might require them to tolerate colleagues quoting from and summarizing the expression of their copyrighted work. Thus, in scholarly fields and reviews-two areas of fair use mentioned specifically by $\S 107-$ actual subjective consent is probably quite common.

Custom may yield some information about the dominant expectations and incentives of a typical copyright owner in a given milieu and may suggest whether copyright owners similarly situated to the plaintiff in a given case would consent to a contested use. It is thus revealing on the issue of whether a typical copyright owner would consent. Also, disturbing the pattern of custom can be expensive. We have already seen, however, that while custom may be suggestive of fair use treatment, it cannot and should not be a sufficient basis for fair use standing alone. See supra notes 122-24 and accompanying text. Inter alia, circumstances that justified the custom may change, and silence on the part of copyright owners does not invariably signal willing acquiescence.

236. Beneficial effects can take many forms. For example, defendant's work can provide publicity for the original. See, e.g., Karll v. Curtis Publishing Co., 39 F. Supp. 836, 837 (E.D. Wis. 1941):

[I]t is very difficult to see how the value of the song could in any manner have been diminished by the article in question. Undoubtedly many thousands who read the article became aware for the first time of the existence of a musical composer by the name of Eric Karll [plaintiff].

See also Liebowitz, supra note 64 , at 9-11.

It has already been noted that copyright owners might be unwilling to license reviewers to produce potentially negative reviews, and that the presence of this possibility favors a grant of fair use when reviews are at issue. In addition, where the reviewers produce positive results for the owner, consent would appear likely. See Professor Latman's discussion of Karll and of the publicity value generally arising from reviews and criticism of scholarly works in A. Latman, The 
receive fair use treatment. ${ }^{238}$ In these cases, consent may be "implied" in the sense that the typical or reasonable copyright owner would probably consent to the use. ${ }^{239}$ The cost in time and money of obtaining consent can be high, both in absolute terms (i.e., constituting a drain on resources) and in relative terms (i.e., high enough to discourage the creation of new works or socially desirable dissemination). ${ }^{240}$ The courts seem to be unwilling to require all users to undertake the cost of obtaining permission from likely-consenting owners; they may feel that such a price is too high to pay for the purpose of protecting that unusual owner who would object to a customary, minor, or beneficial use.

Copyright Law: Howell's Copyright Law Revised and the 1976 Act 205 (5th ed. 1979). See also G. Ricordi \& Co. v. Mason, 201 F. 182, 183 (C.C.S.D.N.Y. 1911) (publicity value of defendant's work noted; motion for preliminary injunction denied), and 201 F. 184 (S.D.N.Y. 1912) (plaintiff's bill dismissed), aff'd, 210 F. 277 (2d Cir. 1913); Latman Study, supra note 102, at 7 n.14. However, the market failure aspect of reviews is present whether or not the review turns out to be favorable. Otherwise, the copyright owner's market right might be used as leverage to obtain unwarranted positive reviews.

Where the primary function of defendant's work is to give increased access to plaintiff's work, this increased access may bring a benefit to plaintiff or at least indicate the noncompetitive relationship between the two works. See New York Times v. Roxbury Data Interface, Inc., $434 \mathrm{~F}$. Supp. 217 (S.D.N.Y. 1977) (defendant's index that was compiled from the New York Times Index, held to be fair use and thus not violative of copyright in the New York Times Index). Among the other factors the Roxbury Data court found relevant was the noncompetitive nature of the two works:

The effect of defendants' personal name index on the market for the Times Index appears slight. Since defendants' index carries citations only to the New York Times Index, defendants' index is useless unless its user has access to the Times Index, from which he will be directed to the articles appearing in the New York Times ..... [P]urchase of defendants' index in no way supersedes the need for plaintiffs' index . . . . Id. at 223-24.

This sensitivity to the economic relation between works is consistent with a general sensitivity to the function of works. See the discussion of function in M. Nimmer, supra note 97, at $\S$ 13.05[B], at 13-65 to 13-72.

237. Traditionally, liability for copyright infringement has been found where copyrighted works are used in ways that compete with their originals. However, two related goods need not be substitutes; they may also be "complements," such that production of one good makes the other more desirable. Substitutes and complements can be exemplified as follows:

[B]utter and margarine are substitutes because a decrease in the price of butter will result

in a decrease in the quantity demanded of margarine-many margarine eaters really prefer the "higher-priced spread." On the other hand ... gin and tonic may be complements since a decrease in the price of gin may increase the quantity demanded of gin, thus increasing the quantity demanded of tonic since gin and tonic tend to be used together.

E. Mansfield, supra note 65 , at 149-50. Complements exhibit negative cross-elasticity of demand; that is, availability of a complement increases demand for the product. On the other hand, positive cross-elasticity is exhibited by substitutes; that is, availability of a substitute generally decreases demand for the product. Determination of whether goods are complements or substitutes is empirical, based on observation of market forces. Id. Complementarity should favor fair use. I am indebted to Warren F. Schwartz here.

238. See supra note 236 .

239. See supra notes $98-100$ and accompanying text.

240. As noted previously, if the costs of doing business (including transaction costs) exceed the anticipated benefits, business will not be done. The result may be that a socially useful work will not be produced. Consider in this regard Judge Breyer's discussion of the impact that the inconvenience of obtaining consent can have on a scientist's use of prior works. Breyer, The Uneasy Case for Copyright, supra note 63, at 316-18. 
In all of these cases, apparent and expected consent act as a substitute for an actual market transaction, indicating that there is no social loss or injury to plaintiff from defendant's use. If transaction costs would inhibit transfers where consent is likely, fair use is an appropriate response. More specifically, in such contexts the second part of the fair use test advocated in this Article is satisfied.

\section{Substantial Injury Hurdle}

Courts do not ordinarily separate the balancing and substantial injury inquiries, although it would probably be agreed that "[h]arm which 'imperils the existence of a publication' is more destructive of a fair use defense than is harm which would 'limit profits.' "241 Several courts have demonstrated a sensitivity to the ultimate issue of whether allowing defendant's use would erode incentives. ${ }^{242}$ For the reasons discussed above, ${ }^{243}$ it would be desirable for the two issues to be separately identified and separately considered in the future.

The economic analysis required by the substantial injury test can aid in integrating the first two parts of the fair use test with traditional fair use law. For example, incentive analysis can help to distinguish between those cases in which a custom of uncompensated use indicates the market can be safely bypassed and those instances in which honoring a custom of such use would harm the copyright scheme. An inquiry into potential market cures, as mandated by the substantial injury hurdle, allows a court to determine whether the circumstances that gave rise to the custom are subject to change, and whether the copyright owners' apparent acquiescence indeed indicates they have no objection to a given use. Without such an inquiry, reliance on custom could bar copyright owners from obtaining needed remuneration, especially for modes of use arising from newly-developed technologies.

Similarly, the identification of market barriers for out-of-print works should be supplemented by an incentive analysis. ${ }^{244}$ If allowing an uncompensated use would seriously prejudice a developing reprint market in such books, fair use would be inappropriate. Courts have recognized the market-impact dimension of the out-of-print problem, without a clear focus on its market-

241. Universal City Studios, Inc. v. Sony Corp. of America, 480 F. Supp. 429, 452 (C.D. Cal. 1979) (citing Fried, Fair Use and the New Act, 22 N.Y.L. Sch. L. Rev. 497, 509 n.53 (1976-77)), rev'd. in part and remanded, 659 F.2d 963 (9th Cir. 1981), cert. granted, 102 S. Ct. 2926 (1982) (No. 81-1687).

242. See, e.g., Meeropol v. Nizer, 560 F.2d 1061, 1069-70 (2d Cir. 1977), cert. denied, 434 U.S. 1013 (1978); Encyclopaedia Britannica Educ. Corp. v. Crooks, 542 F. Supp. 1156, 1174 (W.D.N.Y. 1982) ("Fair use must be reasonable. . . . [I]t is not reasonable to drive plaintiffs from the educational television market."'); Columbia Pictures Corp. v. NBC, 137 F. Supp. 348, 350-51 (S.D. Cal. 1955) (by implication).

243. The substantial injury hurdle embraces a broader category of injury than does the balancing element of the fair use test, and serves different purposes. See supra text accompanying notes 108-24.

244. See supra notes 150-54 and accompanying text, discussing the out-of-print problem in connection with market barriers. 
failure aspect. ${ }^{245}$ Application of the third phase of the market test would serve to reconcile solicitude for the copyright owners' economic interest in out-ofprint works with the Senate Report's apparent concern for maintaining access to these materials.

A model that demonstrates a unification of the three fair use concerns presented here appears in the Agreement on Guidelines for Classroom Copying in Non-For-Profit Educational Institutions. ${ }^{246}$ The Guidelines are simultaneously concerned with brevity, spontaneity, and the cumulative market effect of copying. For example, under the Guidelines, copying that is extensive in quantity or involves "works intended to be 'consumable' in the course of study or of teaching" would not be fair use even if spontaneous and not capable of effectuation in the market. ${ }^{247}$ The Guidelines represent only "the minimum standards" for fair use; the three-part test can serve to structure the fair use inquiry concerning classroom use outside of the Guidelines' parameters. ${ }^{248}$

Overall, the discussion in the preceding sections reveals that incentive analysis can provide a useful addition to the framework for the cases that have grappled with market-oriented approaches to fair use. Now that the nature of the connection between the three-part test and the statute and case law has been explored on a general level, the discussion will turn to two particular scenarios to allow for a more detailed explanation of fair-use analysis.

\section{Case Studies for Fair-Use Analysis}

Both of the cases that follow are relevant to the discussion because they address instances in which the grant of fair use might be favored by public opinion, but the grant is controversial when viewed from a traditional fair use perspective. In Williams \& Wilkins, the first case studied, the court implicitly attempted to use a market approach; in the second, the Betamax case, this market approach was rejected. This reveals some confusion as to the role of both the market approach and the traditional fair-use factors, which might be alleviated if the inchoate doctrinal approach of the fair use cases were reformulated as suggested here. The discussion that follows will suggest how appropriately to apply a market-based test to the Williams \& Wilkins and Betamax situations.

245. See Triangle Publications, Inc. v. Knight-Ridder Newspapers, Inc., 626 F.2d 1171, 1176 n.4 (5th Cir. 1980); Meeropol v. Nizer, 560 F.2d 1061 (2d Cir. 1977), cert. denied, 434 U.S. 1013 (1978).

246. House Report, supra note 10, at 68-70, reprinted in 1976 U.S. Code Cong. \& Ad. News at 5681-84. See supra notes 150-52 and accompanying text, discussing the Guidelines in the context of market barriers.

247. House Report, supra note 10, at 69, reprinted in 1976 U.S. Code Cong. \& Ad. News at 5685 . Such copying could have a significantly adverse effect on the copyright owner's market.

248. House Report, supra note 10, at 68, reprinted in 1976 U.S. Code Cong. \& Ad. News at 5684 ("the purpose of the following guidelines is to state the minimum standards of educational fair use . . there may be instance in which copying which does not fall within the guidelines ... may nonetheless be permitted under the criteria of fair use"'). That the Guidelines were arrived at through interest-group bargaining also suggests the appropriateness of a consent-based analysis. 


\section{A. Williams \& Wilkins}

In Williams \& Wilkins, an equally divided Supreme Court affirmed without opinion a decision by the Court of Claims that extensive library photocopying could constitute fair use. The Court of Claims opinion ${ }^{249}$ implicitly made use of the approach recommended in this Article. It will be useful to apply to that opinion-called "the leading case in the application of the [fair use] doctrine to noncommercial copying"250 - the three-part test described herein, both to illustrate the application of that test and to understand the nature of the decision.

The facts were these: Publisher Williams \& Wilkins Company charged that its copyrights in four medical journals were being infringed by the photocopying efforts of two United States government libraries, the technical library of the National Institutes of Health (NIH) and the National Library of Medicine (NLM). The government conceded that at least one photocopy had been made of eight articles published in one or more of the journals, ${ }^{251}$ but the court's focus was not on those particular copies. Rather, it viewed itself as passing judgment on the libraries' entire photocopying practice. In 1970, NIH made approximately 93,000 photocopies of articles for supply to the NIH research staff. ${ }^{252}$ In 1968, a "representative year," ${ }^{253}$ NLM filled approximately 120,000 requests ${ }^{254}$ from other libraries, government agencies, and private or commercial organizations ${ }^{255}$ seeking photocopies of articles. ${ }^{256}$ The

249. Williams \& Wilkins Co. v. United States, 487 F.2d 1345 (Ct. Cl. 1973), aff'd by an equally divided Court, 420 U.S. 376 (1975) (per curiam). The Court of Claims had reversed the trial court's decision that the United States was liable for infringement, 172 U.S.P.Q. (BNA) 670 (Ct. Cl. 1972).

250. Encyclopaedia Britannica Educ. Corp. v. Crooks, 447 F. Supp. 243, 250 (W.D.N.Y. 1978). The decision in Williams \& Wilkins preceded the 1976 congressional revision of the Copyright Act, Pub. L. No. 94-553, 90 Stat. 2541 (codified as amended in 17 U.S.C. (1976 \& Supp. IV 1980)). As part of the 1976 Act, and in response to the reaction of librarian groups following the commencement of the Williams \& Wilkins suit, Congress enacted 17 U.S.C. § 108 (1976 \& Supp. IV 1980), which provides a structure within which much library photocopying is legally permissable. A. Latman \& R. Gorman, supra note 19, at 519-20. "Section 108(d) might be said to codify the rule in Williams \& Wilkins." Nimmer, supra note 9, at $1056 \mathrm{n} .21$. Nimmer notes, however, that the impact of $\S 108(\mathrm{~g})(2)$ is unclear. That subsection denies protection to "systematic reproduction" of a work, and appears to be responsive to market failure and injury concerns.

Section 108 provides that "[n]othing in this section . . . in any way affects the right of fair use." 17 U.S.C. § 108(f)(4) (1976 \& Supp. IV 1980). But the relationship between $\S \S 107$ and 108 is the subject of some debate. See, e.g., A. Latman \& R. Gorman, supra note 19, at 519. Despite the statutory changes, "[t] questions left open by the new Act." Encyclopaedia Britannica, 447 F. Supp, at 251 n.8. But see Williams \& Wilkins, 487 F.2d at 1359 (ambiguous meaning of "copy" under 1909 Act relevant to fair use finding). See also infra note 273.

251. Williams \& Wilkins, 487 F.2d at 1349.

252. Id. at 1348.

253. Id. at 1349.

254. Id.

255. Id. (" [A]bout 12 percent of the requests came from private or commercial organizations, particularly drug companies.").

256. Id. "Both institutions normally restrict copying on an individual request to a single copy of a single article of a journal issue, and to articles of less than 50 pages." Id. at 1354. 
Court of Claims held that this photocopying activity was protected by fair use. ${ }^{257}$

Application of the three-part test first requires identification of possible market failure. As discussed earlier, ${ }^{258}$ the existence of a noncommercial use may signal a potential market failure, as may the presence of a value such as human health that is not easily monetized. These elements were present in Williams \& Wilkins, for the court stressed that "scientific progress, untainted by any commercial gain from the reproduction, is the hallmark of the whole enterprise of duplication." ${ }^{259}$ Medicine is traditionally a well-paying field, however, and while research may not be as lucrative as practice, the court did not suggest that the photocopy users would fail to be rewarded monetarily for the increase in their skills and accomplishments resulting from their use of the copyrighted work. It is therefore best to look elsewhere for evidence of market failure.

In the Court of Claims's perception, no satisfactory market would form for the valuable medical uses made possible by photocopying if photcopying ceased. ${ }^{200}$ The court believed that the articles desired would not be available for purchase ${ }^{261}$ or that the items desired would not be available except if tied to the purchase of other, expensive items. ${ }^{262}$ But these availability problems become important only if no market for paid photocopies would evolve. As a dissenting opinion pointed out, ${ }^{203}$ it is unclear why the majority felt that photocopying itself would cease being available if the plaintiff publisher were given the judgment of liability it was seeking.

The majority's assumption that photocopying would cease may rest on another type of market defect: high transaction costs. ${ }^{264}$ If each person seek-

257. Id. at 1362-63 and passim. Note that the libraries' self-imposed restrictions (e.g., a refusal to provide articles from recent and widely-available journals to certain users, id. at 1355) were important to the court's finding of fair use. Id. at 1354-56.

258 . See supra notes $163-75$ and accompanying text.

259. 487 F.2d at 1354 . The court also stressed the "personal, individual focus" of the photocopying. Id. at 1355 . Such personal uses may be more readily discouraged by transaction costs. See supra text accompanying notes $155-60$.

260. 487 F.2d at $1356-57$.

261. Id. at 1356 ("[t]he supply of reprints and back numbers is wholly inadequate"). See also id. at 1357 \& n.17 (plaintiff itself gives notice that it does not stock back issues).

262. Id. at 1357.

263. Id. at 1371 (Cowen, C.J., dissenting):

The court has bottomed its decision to a very large extent on its finding, which is not disputed, that medical science would be seriously hurt if the photocopying by defendant's libraries is entirely stopped. But the court goes further and concludes that a judgment for plaintiff would lead to this result. It is not altogether clear to me how the court arrives at the second conclusion, and I think it is based on unwarranted assump. tions.

264. See the discussion of transaction costs supra notes 155-62 and accompanying text. See Goldstein, The Private Consumption of Public Goods: A Comment on Williams \& Wilkins Co. v. United States, 21 Bull. Copyright Soc'y 204 (1974) (recognizing the transaction cost problem but arguing it should not have justified fair use in that case). In addition, the majority seemed to fear that a finding of infringement would lead courts in other contexts, via stare decisis, to enjoin photocopying. Williams \& Wilkins, 487 F.2d at 1360 . Judge Nichols, in dissent, suggested that such injunctions would not necessarily follow. Id. at 1386-87 (Nichols, J., dissenting). In any event, even were an injunction to issue, it might not permanently stop an activity-the prevailing 
ing a photocopy were required to bargain with the copyright owner, the costs and inconvenience of bargaining would prevent many of the uses from being made. ${ }^{265}$ Thus, if conventional modes of bargaining were the only tools available with which to effect transfers, markets might fail to form, and a holding of infringement might end photocopying.

Conventional one-on-one bargaining is not the only alternative, however. Many commentators and plaintiffs themselves had suggested that enforcing the plaintiff's copyright would not preclude a continuation of photocopying. ${ }^{268}$ It was argued that a licensing royalty system or clearinghouse might arise, ${ }^{267}$ reducing transaction costs to a bearable level, so that plaintiffs could be paid and defendants could have use of the copyrighted material. Chief Judge Cowen in dissent presented this position, arguing that a market in photocopies would exist after a judgment of liability, either by means of a reasonable royalty paid via license or by means of clearinghouses, or a combination thereof. ${ }^{268}$

The majority was unwilling to consider these possible market cures. ${ }^{269} \mathrm{It}$ doubted whether the licensing plan suggested by plaintiff would have been "viable," 270 "whether a . . clearinghouse system can be developed without legislation, and if so whether it would be desirable,",271 and it declined to consider author willingness to license. ${ }^{272}$ The majority also felt that the 1909

party, on whose behalf the injunction issues, may be able to sell the enjoined party a right to continue his activity. See Stanford Note, supra note 121, at 248-49. A determination of whether such a market would evolve following an injunction is relevant to assessing substantial injury. See Calabresi \& Melamed, supra note 38 , at 1116.

265. Some of the duplication of effort inherent in such individual transactions might be reduced if the library made the bargaining arrangements, but even then the transaction costs might be prohibitively high. Thus, "[d]efendant suggested at trial that payment of compensation to plaintiff for photocopying its journals would create a continuing undue and oppressive administrative and financial burden on NLM and the NIH library." Williams \& Wilkins, 487 F.2d at 1384 (Cowen, C.J., dissenting). Whether or not the transaction costs would in fact have been "oppressive" was not fully resolved; in the opinion of Chief Judge Cowen, the record did not justify defendant's fears. Id. at 1384-85.

266. Williams \& Wilkins, 487 F.2d at 1360-61. The potential role of licensing and clearinghouses has been explored by many scholars. See, e.g., M. Nimmer, supra note 97, § $13.05[E][4][e]$, at $13-90$ to $13-92$ (discussing a possible judicial role in the creation of compulsory licenses).

267. Williams \& Wilkins, 487 F.2d at 1372, 1378-79 \& n.12, 1384-86 (Cowen, C.J., dissenting).

268. Id. See also id. at 1385 n.17.

269. It did, however, consider whether a market cure might evolve if plaintiff's copyright were not enforced as to photocopies: "It has been suggested ... that publishers now have the power to adopt the intermediate solution of charging more for subscriptions sold to libraries or other entities which engage regularly in photocopying." Id. at 1360 n.26 (emphasis added).

The court placed this unevaluated and seemingly casual suggestion in a footnote rather than addressing the issue more directly and vigorously. If the copyright owners would be able to capture photocopy income even without a liability judgment, that would be relevant to determining what injury the owners would suffer from a fair use holding.

Professor Demsetz has suggested that price discrimination is consistent with efficiency in markets for public goods. See Demsetz, supra note 48, at 300-06. See also Liebowitz, supra note 64, at 12-17 (discussing price discrimination in journals).

270. 487 F.2d at 1360. See also id. at n.24.

271. Id. at 1360 n.24. "The possible intermediate solutions are also of the pragmatic kind . legislatures, not courts, can and should fashion." Id. at 1360.

272. Id. 
Copyright Act foreclosed a court from imposing a licensing system. ${ }^{273}$ This attitude contrasted with Chief Judge Cowen's dissent, which considered it quite relevant that an award to plaintiff "may very well lead to a satisfactory agreement between the parties for a continuation of the photocopying by defendant upon payment of a reasonable royalty to plaintiff."'274

In sum, the majority opinion in Williams \& Wilkins premised its holding on the questionable assumption that certain valuable uses would have to cease if liability were imposed, or at least that there was a high risk that no adequate market would evolve to disseminate the copyrighted works and the socially valuable information they contained to the desired extent. ${ }^{275}$ It was in the context of this assumption that the court made its assessment of harms and benefits.

In broad outline, the court's approach to costs and benefits followed the pattern recommended here. The majority balanced the harm that would be imposed on medical science by a decision in favor of liability ${ }^{276}$ with the harm that would be imposed on the publisher by a finding of fair use, ${ }^{277}$ and concluded that the "balance of risks" was on defendant's side. ${ }^{278}$ This implicitly satisfied the second branch of the fair use test described herein. ${ }^{270}$ The majority also concluded that the publisher would suffer no "serious adverse impact," ${ }^{280}$ a conclusion that, if true, would satisfy the substantial injury hurdle that is the third part of the fair use test. ${ }^{281}$ A closer look at the court's analysis, however, reveals flaws in its approach.

273. "[U]nder [the 1909 statute] . . . we have the choice only of thumb's up or thumb's down, for the photocopying practice involved in this litigation, without any real Congressional guidance. Intermediate or compromise solutions are not within our authority." Id. (footnote omitted). But see M. Nimmer, supra note 97, § 13.05[E][4][e], at 13-82 to 13-86.

In addition to the general limitations of copyright law that might affect other courts, the Court of Claims lacked the power to enjoin governmental libraries. 487 F.2d at 1346 n.1. See 28 U.S.C. § 1498 (1976 \& Supp. IV 1980).

274. 487 F.2d at 1372 (Cowen, C.J., dissenting).

275. Id. at $1360,1362-63$.

276. Id. at $1356-57,1362-63$, and passim.

277. Id. at 1357-59.

278. Id. at 1359.

279. See supra text accompanying notes $92-103$. Note, however, that the court declined to prescribe a general rule using balancing methodology:

[O]ur holding rests upon this record which fails to show a significant detriment to plaintiff but does demonstrate injury to medical and scientific research if photocopying of this kind is held unlawful. We leave untouched, because we do not have to reach them, the situations where the copyright owner is shown to be hurt or the recipients (or their interests) would not be significantly injured if the reproductions were ruled to infringe.

487 F.2d at 1362-63. This is consistent with the Court of Claims's overall reluctance to state general rules in this case:

[T] he conclusion that defendant's particular use . . . has been 'fair' rests upon all of the elements discussed [in a previous portion of the opinion] and not upon any one, or any combination less than all. We do not have to, and do not, say than any particular component would be enough . . . . Conversely, we do not have to, and do not, say that all the elements we mention are essential ....

Id. at 1362.

280. Id. at 1359.

281. See the discussion of the substantial injury hurdle, supra text accompanying notes 
The majority's opinion recognized that the first step in the balancing process is the determination of whether defendant's use serves public welfare. ${ }^{282}$ Given the nature of medical research, the court had no trouble with this inquiry. The court then discussed how this interest would be hurt (i.e., what benefits would be lost) if liability were imposed; unfortunately, the court concentrated this discussion on an examination of how medical science would be affected if photocopying were ended. ${ }^{283}$ As seen above, however, it is not certain that an end to photocopying would indeed have followed from a judgment of liability. The failure to consider the possibility that photocopying might continue under royalty arrangements overstated the amount at stake for medical science.

The court's evaluation of harm to plaintiff is also questionable in some respects. In particular, the court refused to include in its assessment of plaintiff's injury the potential photocopy royalty income that the plaintiff might have received if its copyright were enforced. The court wrote:

It is wrong to measure the detriment to plaintiff by loss of presumed royalty income-a standard which necessarily assumes that plaintiff had a right to issue licenses. That would be true, of course, only if it were first decided that the defendant's practices did not constitute "fair use." In determining whether the company has been sufficiently hurt to cause these practices to become "unfair," one cannot assume at the start the merit of the plaintiff's position . . . . ${ }^{284}$

By contrast, the economic approach to fair use presented in this Article begins with the premise that a copyright owner is ordinarily entitled to revenue for all substantial uses of his work within the statutorily protected categories. ${ }^{285}$ Both fairness to the copyright owner and economic efficiency demand that the assessment of his injury include the loss of the revenues he would receive in the market were his entitlement to be enforced. If the market would not fail fully after a finding of liability, the plaintiff would be able to serve the public interest by selling his work at least to some extent. If such revenues were possible in substantial amounts, then their presence or absence could have a significant impact on the copyright owner's incentives and his patterns of

104-24. The court found that the record failed to "show a serious adverse impact, either on plaintiff or on medical publishers generally, from the photocopying practices of the type of NIH and NLM." 487 F.2d at 1359 (emphasis added). The court was thus looking to the impact of its decision on the marketplace as a whole, which is consistent with the substantial injury hurdle. See supra text accompanying notes 115-24.

282.

Whether the privilege may justifiably be applied to particular materials turns initially on the nature of the materials, e.g., whether their distribution would serve the public interest in the free dissemination of information and whether their preparation requires some use of prior materials dealing with the same subject matter.

487 F.2d at 1352-53 (quoting Rosemont Enters., Inc. v. Random House, Inc., 366 F.2d 303, 307

(2d Cir. 1966)).

283. "There is no doubt in our minds that medical science would be seriously hurt if such library photocopying were stopped." Id. at 1356 . See supra notes 260-75 and accompanying text. 284. 487 F.2d at 1357 n.19.

285. Certain uses are not within protected categories at all, of course. See generally 17 U.S.C. § 106 (1976). 
production. ${ }^{288}$ To deny consideration to such potential revenues would be to place impossible burdens on most plaintiffs, ${ }^{287}$ rendering them incapable of demonstrating the substantial injury that might follow from a grant of fair use.

Thus, although the Williams \& Wilkins decision evidences a concern with market failure similar to that discussed here, the opinion suffers from a lack of an articulated and coherent rationale. ${ }^{288}$ An explicit focus on the issues of market failure, balancing and substantial injury would have eliminated some of the pitfalls discussed above. Nevertheless, the debate between majority and dissenters in Williams \& Wilkins focused properly not on formalistic questions, but on key issues such as whether or not markets would form. In doing so, the judges of that court addressed one of the central questions in the debate over whether copyright law can be adapted to the new technologies.

\section{B. The Betamax Case: Intrinsic Uses}

In the Betamax case, the Ninth Circuit reversed a district court judgment that home videorecording constituted fair use. ${ }^{289}$ In doing so, it strongly criticized the district court for using "Williams \& Wilkins Co.'s distortions of the fair use rationale." ${ }^{200}$ The "distortion" that primarily disturbed the Ninth Circuit was the Court of Claims's willingness to extend fair use treatment to the use of a work "for its intrinsic purpose-to make what might be called the 'ordinary' use of it." ${ }^{201}$ The Ninth Circuit relied heavily on Leon Seltzer's contrary view that fair use generally should deal only with " "the use by a second author of a first author's work.' ", 292 It also intimated that it accepted Seltzer's belief that "ordinary" use by photocopying and videorecording " 'triggers questions of reallocation of costs," "203 that such questions should be dealt with in specific exemptions rather than by fair use, and that they are thus "matters for Congress, not the courts." 284

Turning initially to the proposition that "ordinary" use is not within the proper ambit of the fair use doctrine, one finds that the copyright statute itself

286. See supra text accompanying notes 122-24.

287. The court put a burden of demonstrating detriment on the plaintiff. 487 F.2d at 1359 . This Article has suggested that this burden should be placed on the plaintiff only where the defendant has made a convincing showing that the market between owner and user is so unlikely to function properly that the assumptions underlying the statutory damage provisions are undermined. See supra notes 137-44 and accompanying text. The Court of Claims's allocation of the burden indeed arose in part from the court's perception that the situation failed to conform to any perfect market model. 487 F.2d at 1358-59. But the court's insufficient consideration of market structure left in doubt whether the market failure was sufficiently likely or severe to justify this crucial shift in burden.

288. See supra note 279.

289. Universal City Studios, Inc. v. Sony Corp. of America, 659 F.2d 963 (9th Cir. 1981), modifying 480 F. Supp. 429 (C.D. Cal. 1979), cert. granted, 102 S. Ct. 2926 (1982) (No. 81-1687).

290. Id. at 970 (emphasis omitted).

291. Id. at 970 (quoting L. Seltzer, supra note 4, at 24 ).

292. Id. (quoting L. Seltzer, supra note 4 , at 24 (emphasis omitted)).

293. Id. at 971, (quoting L. Seltzer, supra note 4, at 38 (emphasis omitted)).

294. Id. at 971 . 
specifically embraces at least one "ordinary" use among the examples for which fair use is appropriate: "multiple copies for classroom use" find explicit shelter under section 107.295 In addition to the explicit wording of section 107, legislative history shows Congress treating photocopying and recording as legitimate subjects for resolution under the fair use doctrine. ${ }^{296}$ Similarly, the Ninth Circuit did not deny that home taping of sound recordings, as "intrinsic," "ordinary," consumer-type use, long considered permissible, might constitute fair use. ${ }^{297}$

It is true that, historically, new authors were given fair use treatment more often than ordinary users. The reason may simply be that most markets are set up to serve ordinary consumers, and usually function well in that context; market failure will arise more often in circumstances where users seek to employ the work in unexpected ways and fair use will thus tend to be awarded in such circumstances. In addition, the public interests served by second authors are likely to be stronger than the interests served by ordinary consumers ${ }^{298}$ and injury to incentives may be less severe when the user is a second author, ${ }^{299}$ whose use is unlikely to be repeated by others, and whose work, by being different from the copyrighted work, may not be competitive with it for the same ultimate audience. But none of these functional consider-

295. 17 U.S.C. § 107 (Supp. IV 1980).

296. See House Report, supra note 10, at 65-74, reprinted in 1976 U.S. Code Cong. \& Ad. News at 5678-88; Senate Report, supra note 26, at 61-67. See also the congressional debate regarding sound recordings, 117 Cong. Rec. 34, 748 (1971) (statement of Representative Kastenmeier) (child's home recording of broadcast of music for listening pleasure is fair use), quoted in Universal City Studios, Inc., 480 F. Supp. at 446.

297. The Ninth Circuit addressed the issue of home sound recordings in terms of an exemption potentially arising out of the Sound Recording Amendment of 1971. (The Ninth Circuit inquired whether, if such an exemption existed, it would apply to home video-tape recording. The court concluded that it would not.) However, such characterization is erroneous. Whether or not persons who make tape recordings of music at home are copyright infringers is an issue that cannot be resolved solely by reference to an exemption potentially arising out of the 1971 legislative history. See Nimmer, supra note 125, at 1505 . Long before the Sound Recording Amendment of 1971, the copyright in musical compositions (including, e.g., musical scores) could be infringed by the making of unauthorized recordings. See $\S 1(\mathrm{e})$ of the Copyright Act of 1909, 35 Stat. 1075, codified and reenacted 1947, amended 1976. When Congress in 1971 expressed a belief that home audio recording "over the past 20 years" was not an infringement, Nimmer, supra note 125, at 1509 (quoting H.R. Rep. No. 987, 92nd Cong., 1st Sess. 7, reprinted in 1971 U.S. Code Cong. \& Ad. News 1566, 1572), the only possible legal basis for that belief was fair use. Id. at 1509-11. See also remarks of Representative Kastenmeier, 480 F. Supp. at 446 (discussed in Nimmer, supra 125, at 1511-12). Thus it is fair use that must be applied if home audio recording is to be immune from liability, and such recording is clearly "an intrinsic use."

Professor Nimmer argues that although "[c]ourts and commentators have assumed that audio home recording is beyond the reach of copyright laws," Nimmer, supra note 125, at 1505, such recording should be considered an infringement. In making this argument, he relies on Seltzer's view that intrinsic uses should not be granted fair use treatment. Id. at 1521-22. However, Professor Nimmer himself urges in support of his conclusion the practicality of various methods of payment, thus revealing an implicit concern with market cure. Id. at 1525-34. Moreover, he intimates a willingness to accept an economic justification for fair use. See id. at 1530 n.88.

298. On the other hand, ordinary consumers are more likely to be deterred by transaction costs. See supra note 259 .

299. See supra text accompanying notes 115-16. 
ations suggest there should be a per se bar against awarding fair use to ordinary users; on the contrary, in the case where the transactions between copyright owner and ordinary user exhibit the same characteristics of market failure, small injury, and public interest, fair use may well be appropriate. ${ }^{300}$ The court of appeals stated that the inclusion of photocopying, videorecording, and other "intrinsic" uses within fair use would cause "a fundamental restructuring of the copyright system not justified by the statutory scheme or traditional notions of fair use." ${ }^{301}$ This Article, however, has shown that it is the user faced with market failure, whether he is a second author or an "ordinary" user, who is the traditional judicial and statutory object of fair use solicitude.

In light of the Ninth Circuit's reliance on Leon Seltzer's "intrinsic use" terminology, it is important to note that Seltzer's own underlying approach to fair use is arguably adaptable to a market failure analysis. He suggests that "a more useful fair use statute" 302 than the one enacted by Congress would begin as follows: "Fair use is use that is necessary for the furtherance of knowledge, literature, and the arts AND does not deprive the creator of the work of an appropriately expected economic reward." ${ }^{303}$ On the surface, Seltzer's prohibition against extending fair use to "ordinary" uses would seem to follow quite logically from his ideal statute's concern with appropriately expected economic reward: the ordinary user is precisely the person from whom the copyright owner expects remuneration, so that granting fair use to such person would violate Seltzer's statute by "depriving the creator . . . of an appropriately expected economic reward." But, where there is market failure, enforcing the owner's rights may not bring economic reward; more fundamentally, the author's normal expectations will involve his evaluation of what kind of markets exist for his work. In the presence of market failure, "ordinary" users become extraordinary, and fair use can be granted without deprivation of "appropriately expected" receipts. Thus, ordinary users faced with market failure might have some claim to fair use under the basic clause of Seltzer's proposed statute. ${ }^{304}$

300. See generally supra notes $88-124$ and accompanying text.

301. 659 F.2d at 971 .

The Ninth Circuit also asserted that use of the Williams \& Wilkins approach would undermine incentives, id. at 970 , and that such an approach would put copyright holders "in the unenviable position of proving damage in a context in which extreme difficulty is acknowledged," id. at 971 . This Article has suggested that a substantial injury hurdle and sensitive application of burdens of proof can avoid these dangers. See supra notes 104-24 \& 135-48 and accompanying text. The Ninth Circuit noted that "home users assign economic value to their ability to have control over access to copyrighted works," and that "[t]he copyright laws would seem to require that the copyright owner be given the opportunity to exploit this market." 659 F.2d at 974. Without an exploration of market cures, however, it is unclear whether such opportunity could be exploited and what constitutes the "potential market" for the copyrighted works.

302. L. Seltzer, supra note 4 , at 31.

303. Id. (emphasis omitted).

304. Seltzer himself does not develop his basic clause in this way, of course. See id. at 36 ("Fair use, if it is to have any coherent meaning, must by itself suggest to both creator and society that it is not part of the normal market."(emphasis in original)). Seltzer's ideal statute would not appear to direct a court to take into account the economic and structural context in which 
The Ninth Circuit's reliance on Seltzer's conclusions regarding intrinsic use is also questionable since, as Seltzer acknowledged, Congress did not follow his recommended pattern. ${ }^{305}$ In particular, Congress did not adopt any strict conceptual distinction between those uses properly treated by exemptions and those properly treated by fair use. ${ }^{306}$ Seltzer argued that Congress erred in doing so; ${ }^{307}$ this Article argues that the legislation accurately reflected past judicial developments. In any event, the open-ended nature of the congressional approach to fair use suggests that endorsement of an inflexible standard like "intrinsic use" would be inappropriate.

A market-oriented test would be more consistent with this flexible congressional approach, and is capable of addressing the Betamax problem. Under the proposed three-part test, the first issue would be to identify whether market failure potentially appears in the home videorecording context. It does, in two areas. Home users might well find transaction costs prohibitively high if they were required to bargain individually with copyright owners over the right to tape each desired program. The mere task of identifying the copyright owners in advance of broadcasts might present insurmountable difficulties. Second, prohibitions against home taping might be impossible to enforce; the potential loss of privacy might pose a cost higher than the society would wish to bear, ${ }^{308}$ and the economic cost to the copyright owners of identifying potential violators and bringing them to justice might be greater than any profits likely to be generated by deterrence of unauthorized taping. ${ }^{309}$ Bargains that cannot be enforced present a classic type of market failure. ${ }^{310}$

Theoretically, it is possible that both aspects of the market failure could be cured if the manufacturers of videorecorders and videorecording tape are subjected to liability judgments. ${ }^{311}$ The court could potentially "award damages or a continuing royalty," 312 which would act as an incentive to the liable parties to set up a workable collection system, or the court might itself take steps toward such a system. ${ }^{313}$ Among the suggestions that have been dis-

defendant's use appears. Rather, he suggests that the second clause of his ideal statute might read:

"In determining whether the use made of a work in a particular case deprives its creator of such a reward, account should be taken first of the nature of the copyrighted work and then of the purpose, character, and extent of the use." Id. at 36 (emphasis omitted).

305 . Id. at $27-28,40$.

306. Id. at $27-28$.

307. Id.

308. See Universal City Studios, Inc., 480 F. Supp. at $446,454,468$.

309. In the event of a criminal violation, the government would of course bear the transaction costs. However, criminal liability for infringement applies only to "[a]ny person who infringes a copyright willfully and for purposes of commercial advantage or private financial gain." 17 U.S.C. § 506(a) (1976).

310. See supra note 48 .

311. Defendants in Universal City Studios, Inc. included, inter alia, the manufacturers of the Betamax videorecorder and of videorecording tapes. 659 F.2d at 964 . See Stanford Note, supra note 121 , at $257-62$.

312. Universal City Studios, Inc., 659 F.2d at 976.

313. Query whether these remedies are within the court's own injunctive powers. See Stanford Note, supra note 121, at 261; supra notes 129-34 and accompanying text. Also, a court 
cussed are imposing royalty charges to be collected at the time of recorder or tape purchases as an "add-on" to the price. ${ }^{314}$ Collection of the royalty fees and monitoring of the collection process might thus be practicable, easing the enforcement burden. A centralized agent might receive and distribute the royalty funds proportionately to the owners of popular programs at a level of transaction cost less than that which would be necessary if individual bargains were to be required. ${ }^{315}$

Viewed from this perspective, the key questions are whether such market cures will evolve, whether they will be practicable, and what ought to be a court's role in achieving them. The Betamax case might be decided either way under this analysis, depending on what additional findings were made. If a market cure were achievable through a finding of liability, and if a grant of fair use would deprive the plaintiffs of substantial revenues from this potential market, fair use would be inappropriate because the substantial injury hurdle could not be surmounted. If, however, the court determined that a market cure were not practicable, further inquiry would follow. The court would then "weigh . . . the 'benefit' of an extremely popular increase in access with the 'harm' to a plaintiff." 316 If the court found that the balance favored defendants, and if it found that judgment for defendants would not substantially injure plaintiffs' incentives, fair use would be granted; otherwise, liability would be imposed.

Neither the district court nor the court of appeals adequately addressed the question of market cure. The district court held that even if home taping constituted copyright infringement, the manufacturers would not have been liable. ${ }^{317}$ Under such a view, the possible market cure discussed above would be unavailable. ${ }^{318}$ The court of appeals imposed liability on the manufacturers. ${ }^{319}$ If that court was correct in its approach to contributory liability, such market cures are potentially in the hands of the courts. However, the court declined to focus on the question. ${ }^{320}$ In fact, it rejected the notion that the practicability or availability of relief (i.e., market cure) should be relevant to

should consider the administrative costs of its own actions in deciding on what course to follow. If administrative costs are high in relation to the benefits expected, an attempt at market cure may be undesirable.

314. See Stanford Note, supra note 121, at 261-62; McCullaugh, Shock Vibrates through Industry, Billboard, Oct. 31, 1981, at 1 . See also Demsetz, supra note 48, at 306 ("'In many instances it may be possible to tie in the consumption of a second product with consumption of the collective good, and private incentives may very well exist for the production of the tied-in good because exclusion is possible."). Of course, further factual investigation would be necessary to know if such market cures would be practicable. See, e.g., McCullaugh, supra ("execution and administration" of hardware surcharge system viewed by some as "nightmarish").

315. Performing rights societies serve a similar function for musical works today, under judicial antitrust supervision. See A. Latman \& R. Gorman, supra note 19, at 455-58.

316. Universal City Studios, Inc., 659 F.2d at 971 . The Ninth Circuit accurately described the procedure while rejecting it.

317. 480 F. Supp. at 457-62. See also the district court's discussion of injunctive relief, id. at 463-69.

318. "[R]equiring copyright holders to sue individual home users might amount to a total exemption for the Betamax ...." Stanford Note, supra note 121, at 258.

319. 659 F.2d at $974-76$.

320. It seemed to assume that such a cure was possible, however. See id. at 976-77. ("[D]amages or a continuing royalty ... may very well be an acceptable resolution in this 
the issue of liability versus fair use. ${ }^{321}$ It thereby imposed on society the deliberately unconsidered risk that either access would cease, or that widespread and unredressed copyright violations would bring the law into disrepute or ridicule. Once the court of appeals rejected the district court's view of contributory liability, it should have remanded the case for further findings on the issue of market cure.

\section{Summary}

The Williams \& Wilkins court seemed to focus primarily on the social interests served by defendant's photocopying practices. The Betamax court seemed to focus on the property owner's interests. It is hoped that the threepart test presented here can unify both perspectives.

\section{CONCLUSION}

An economic and structural analysis of the fair use doctrine and its place in the copyright scheme reveals that fair use is ordinarily granted when the market cannot be relied upon to allow socially desirable access to, and use of, copyrighted works. This Article has presented a three-part test for fair use that reflects this focus on market failure, and has traced how this test could be incorporated within the traditional approach to fair use. Moreover, the discussion of the Williams \& Wilkins opinion, which most closely applied the three-part test, and of the Betamax case, demonstrated that the test can provide a framework in which the courts can directly face the underlying issues that should govern the application of fair use doctrine to new technologies.

It is important that a market failure approach to fair use not be expanded into a justification for allowing court intervention whenever the market fails to reach "perfect" results, for no market is ever perfect. What emerges from the case law and the copyright statute is a focus on individual types of transactions, not a concern with restructuring an entire set of markets to reach ideal goals, and an identification of those imperfections that will not be tolerated because of their particular impact on dissemination and the ultimate goals of copyright, That transactional emphasis is the proper one. It allows particularly desirable transfers that are blocked by market failure to go forward outside the market, but also allows the courts to impose liability where widespread use of this bypass would cause substantial injury to the copyright owner. This Article has accordingly discussed not only the market failure grounds for fair use, but also the limitations that should be placed on employment of the doctrine. It is submitted that the three-part test presented here is of assistance in analyzing fair use issues and provides a helpful tool for predicting and guiding decisions in this most difficult area of copyright law.

context."). Among the sources cited by the Ninth Circuit was the Stanford Note, supra note 121, which discussed methods of market restructuring. See 659 F.2d $966 \mathrm{nn} .1,2$. Explicit consideration of the possibility was necessary, to avoid misunderstandings and ridicule on the one hand, and, on the other, to avoid the danger of a complete cessation of use of the new technology. See supra note 124 (discussing popular reactions to the Ninth Circuit decision).

321. 659 F.2d at 976. 